\title{
The Canonization of the University Patron: The 617st Academic Year at the Pontifical University of John Paul II in Krakow
}

Without a doubt, one of the most important events of the past academic year was the canonization of our founder, Pope Blessed John Paul II. It is especially worth noting that the decision about the canonization and its date was announced publicly precisely on the day of our university's pilgrimage to Kalwaria Zebrzydowska. It was during a consistory on September 30th 2013 that Pope Francis announced that he would canonize two popes, John XXIII and John Paul II, on April 27th 2014, Divine Mercy Sunday.

It immediately became apparent that this would be a unique event that would forever remain etched in our memories. Along with the inauguration of the new academic year, preparations for the fullest experience of the canonization of John Paul II - the founder, caring guardian and ultimately illustrious patron of the university - were undertaken. These were not only preparations related to the organization of travel to the canonization ceremony, but above all those whose purpose was to deepen the knowledge of the great Polish pope and the popularization of his teachings. Symposia and academic conferences organized on this occasion will be presented below in separate summaries.

It was with great joy that we heard the words of the formula for canonization on Divine Mercy Sunday when Pope Francis ceremoniously declared: "For the honor of the Blessed Trinity, the exaltation of the Catholic faith and the increase of the Christian life, by the authority of our Lord Jesus Christ, and by of the Holy Apostles Peter and Paul, and our own, after due deliberation and frequent prayer for divine assistance, and having sought the counsel of many of our brother bishops, we declare and define Blessed John XXIII, John Paul II, to be saints, and we enroll them among the saints, decreeing that they are to be venerated as such by the whole Church. In the name of the Father, and of the Son, and of the Holy Spirit." In his homily, the pope reminded the faithful that: "John XXIII and John Paul II cooperated with the Holy Spirit in renewing and updating the Church in keeping with her pristine features, those features the saints have given her throughout the centuries. Let us not forget that it is the saints who give direction and growth to 
the Church." This fact obliges us to imitate them in their feeling of responsibility for today's Church.

One day after the canonization (April 28th 2014), Cardinal Stanisław Dziwisz, Grand Chancellor of our university, also alluded to responsibility for the Church during the thanksgiving Mass at St. Peter's Square. During the introduction to the Mass, he said: "We rejoice that we have a great advocate for our affairs in heaven. We also understand that this gift also is a challenge. Thus we should all aim for the ideals written down in the Gospels, the ideals realized by St. John Paul II."

The university authorities were led by His Magnificence Rev. Prof. Władysław Zuziak, Rector of the university, and faculty and students. The faculty and students attended the ceremony in two distinct groups of pilgrims. Rev. Dr. Hab. Maciej Ostrowski along with the Chancellor Rev. Andrzej Lichosyt and the Kraktours travel agency organized the faculty pilgrimage. After the canonization and thanksgiving ceremonies, the faculty pilgrimage participants visited certain historical sites in Rome and took the opportunity to relax in picturesque Umbria. Meanwhile, the students' pilgrimage, which was organized by the Students' Union, took them this time to above all visit Rome's historical sites. The canonization ceremonies were above all an especially joyous experience for all the participants, one that enriched them spiritually and filled them with a feeling of pride.

Although chronologically it happened earlier, a second event that undoubtedly had great significance for the development of the university was the creation of a new faculty, the Faculty of Canon Law. It was erected by a decree of the Congregation for Catholic Education on March 19th 2014. This faculty was created on the basis of the Institute of Canon Law, which was created in 1999. The creation of the Faculty of Canon Law at our university refers to the rich tradition of the teaching of canon law in Krakow, which previously helped create the history of the Jagiellonian University.

Rev. Prof. Dr. Hab. Tomasz Rozkrut was appointed as Dean of the new faculty, and Rev. Dr. Andrzej Sosnowski, CR, was appointed as its Associate Dean. Meanwhile, its lecturers (docentes stabiles) who were approved by the congregation, were: Rev. Prof. Dr. Hab. Tomasz Rozkrut; Dr. Aleksandra Brzemia-Bonarek; Rev. Dr. Marek Gołąb; Rev. Dr. Andrzej Sosnowski, C.R; Rev. Dr. Piotr Steczkowski; Rev. Dr. Andrzej Wójcik; and Rev. Dr. Arkadiusz Zakręta, C.M.

The Faculty of Canon Law has the right to give the academic degree of Licentiate of Canon Law (canon law licentiate). Its possession is a necessary precondition for the admission to higher functions in ecclesiastical courts as well as to give lectures in canon law in seminaries. Studies in canon law also prepare one to work in Church administration. Graduates of the faculty can also work as professionals in parish counseling regarding marriage annulments. 
The third important event that is strong evidence of the development of the university is the creation of new majors of study. Thanks to this, the Faculty of Theology recast the already existing specialization in Religious Tourism into an area of study of the same name. The university Senate confirmed this decision on January 20th 2014. Studies in this area began in the 2014-2015 academic year. These are three-year studies (which give a professional Baccalaureate degree), which impart ethical and theological knowledge, as well as that related to art and the religious culture of various countries. These studies also develop the capabilities that are necessary to serving pilgrims and tourists, which also requires knowledge of touristic geography and of pilgrimages. Students of this major also complete internships in well-known pilgrimage sites and other places visited by many tourists.

Meanwhile, three new majors were created at the Faculty of History and Cultural Heritage: Historical and Social Sciences; Archival Science and Management of Documentation; and Historical Tourism. All these majors lead to a professional Bachelor of Arts degree (they each last three years). Historical and Social Sciences were inaugurated after a decision of the Senate on January 20th 2014, while studies in the Historical Tourism and Archival Studies and Management of Documentation impart knowledge of the social and political sciences about the mechanisms that direct social structures and also develop the capacities allowing for the recognition and analysis of social, economic, legal, cultural, ethnic and religious matters. These majors prepare students for public work in administration at both the national and local levels, in international institutions and in non-governmental organizations. Next, the Historical Tourism major imparts knowledge of the humanities, especially history, art history, the history of religion and culture. They develop the skills that are necessary to work in the tourism industry and in institutions related to the service of tourism and international exchanges. Finally, the Archival Studies and Management of Documentation major deals with the study of phenomena from world history and the history of religion and culture, and the history of public administration and historical geography. They prepare graduates for work in archives, museums, libraries, banks and businesses.

Another important event with significant importance for the development of the university was the finalization of the "Effectiveness of Management and the Quality of Education As a Measure of Success at the Pontifical University of John Paul II" financed by the European Social Fund as part of its Human Capital Operational Program (sub-measure 4.1.1.). The realization of this project began on September 1st 2012 and lasted until August 31st 2014. Its purpose was the strengthening of the didactic potential of the university. In it, a total of 194 partial tasks for which 3.6 million zlotys from European funds were allotted were realized. Our university became enriched by precisely such a sum. As part of the 
project, the following aims related to the improvement of the management processes were realized: the management of the teaching process and the quality of education in cooperation with employers; management of the scientific process, knowledge and intellectual property; estate, finance and risk management; human resources management; and the development of the competences of the managers. At the same time, there were training courses that dealt with the following areas: the basics of personnel management, interpersonal communications, management of oneself in difficult situations, conflict management, the acquiring of external funds for the development purposes of the university, the basics of sponsoring and fundraising, project management, public auctions in post-secondary schools, responsibility for the infringement of the discipline of public finances in post-secondary schools and oversight of public finances in post-secondary schools; management control in post-secondary schools; the Polish Qualifications Framework; the process of the commercialization of academic research; research project management; taking advantage of knowledge resources of the Pontifical University of John Paul II in Krakow; the protection of intellectual property; anti-plagiarism protection; budgeting and controlling; operation of the Pensum, Plany and Stypendia ("Plans and Stipends") computer programs; the evaluation of staff; the career development of staff. Furthermore, there were developed documents (terms of use, provisions and procedures) describing the specific activities of various institutions of the university, such as: "Procedures and tools in the Field of Knowledge Management at the Pontifical University of John Paul II"; "The Terms of Use of Property Law Management"; and "The Implementation of Rules, Procedures and Tools in the Field of the Process of Managing Research Projects at the Pontifical University of John Paul II". In total, 21 such documents were laid down and submitted to the university Senate for approval. Computer systems for the needs of the library and The Pontifical University of John Paul II in Krakow Press were also purchased and implemented. Also, the modules of electronic service for the APR and SIMPLE systems that the university uses and other essential programming elements, computer hardware, electronic equipment for the service of the purchased systems and electronic equipment for didactic workshops and office furnishing were also purchased.

Finally, a very important event in the past academic year was the acquiring of a new building on Bernardyńska Street 3 in Krakow (next to Wawel Castle). This will allow for a solution to the lack of didactic and administrative facilities in the coming years. This was possible thanks to the kindness of His Excellency Archbishop Wacław Depo, the archbishop of Częstochowa, who let us lease this building, which was previously occupied by the Major Seminary of the Diocese of Sosnowiec (which was moved to Częstochowa), as well as His Eminence Cardinal Stanisław Dziwisz, who supported our efforts in this matter, as well as 
thanks to the engagement of our new Chancellor Rev. Andrzej Lichosyt. Since October 1st 2013, didactic activities, conferences and rehearsals of the Psalmodia choir are held here. In addition to lecture halls and classrooms, this building also houses faculty chairs, professors' apartments, a chapel and an oratorium. Also transferred here was part of the university administration (including the secretariat of the Institute for Studies on the Family and the Institute of Social Work), the Students' Union, the Graduate Students' Union and the headquarters of the St. Hedwig the Queen Foundation for the Pontifical University of John Paul II. Additionally, there were created there the Kawiarenka Film Caffe café, which can house 25 people; and a cafeteria, which offers warm meals at accessible prices for students, professors and confernce participants.

Like previous academic years, the 2013-2014 academic year began with the traditional pilgrimage of our community to the Marian shrine in Kalwaria Zebrzydowska on Monday September 30th 2013. The first part of program was the conference "O możliwości wiary dzisiaj" ("Concerning the Possibility of Faith Today") given by Rev. Dr. Hab. Robert Woźniak from the Faculty of Theology. Next, there was a ceremonious concelebrated Mass led by the university's Rector Rev. Prof. Władysław Zuziak. Rev. Dr. Andrzej Przybylski, Rector of the Major Seminary of the Archdiocese of Częstochowa, gave the homily. In the afternoon, the Stations of the Cross prepared and led by theology students were held at the routes of Kalwaria Zebrzydowska. Professors, academic staff and students of the university (including diocesan and regular seminarians of Krakow, members of female religious orders and lay students) took part in the pilgrimage. During the pilgrimage, prayers through the intercession of Our Lady of Calvary were said in particular for a solid preparation of the university for the canonization of Blessed John Paul II, the founder of our university (which then was the Pontifical Academy of Theology in Krakow) and for God's blessings for the university.

The ceremonious inauguration of the 2013-2014 academic year took place on Wednesday October 16th 2013. The inauguration date is a reference to the date of Blessed John Paul II's ascent to the throne of St. Peter (on October 16th 1978). As usual, the inauguration ceremony consisted of a liturgical part in St. Anne's Collegiate Church, and of an academic one in the auditorium of the Karol Szymanowski Philharmonic in Krakow. The ceremonious inauguration Mass was led by His Eminence Cardinal Stanisław Dziwisz, Archbishop of Krakow and the university's Great Chancellor. Meanwhile, His Excellency Bishop Tadeusz Rakoczy, bishop of Bielsko-Żywiec, gave the homily. During the Mass an unusually important event took place: the blessing of the university's new banner by Cardinal Dziwisz.

In relation to this fact, Bishop Rakoczy emphasized the significance of the banner: "It is with this banner that you confirm the previously undertaken choice 
of the Holy Father John Paul II for your patron. This banner always was always a recognizable sign, and it was the object of pride and respect [...]. May this be a sign of unity, engagement and promotion of the university, and of its high moral and intellectual level." The main symbol on the banner is a coat of arms created from crossing keys modeled on the keys from John Paul II's coat of arms.

After the Mass, the participants of the inauguration walked in a ceremonious procession to the hall of the Karol Szymanowski Philharmonic in Krakow, where after singing "Gaude Mater Polonia” His Magnificence Rev. Dr. Hab. Władysław Zuziak, the university's Rector and a professor at the Pontifical University of John Paul II. Next, the Rector greeted the university's Grand Chancellor Cardinal Dziwisz and later the gathered guests, who included: His Eminence Cardinal Franciszek Macharski; Archbishop Józef Kowalczyk, Primate of Poland; Wacław Depo, Archbishop of Częstochowa; Tadeusz Rakoczy, Bishop of Bielsko-Żywiec; Bishop Andrzej Jeż, Bishop of Tarnow; Grzegorz Kaszak, Bishop of Sosnowiec; Jan Wątroba, Bishop of Rzeszów; Jan Szkodoń, Auxiliary Bishop of Krakow; Jan Zając, Bishop Emeritus of Krakow; Damian Muskus, Auxiliary Bishop of Krakow; Grzegorz Ryś, Auxiliary Bishop of Krakow; Member of Parliament Mr. Ireneusz Raś; Member of Parliament Ms. Katarzyna Matusik-Lipiec; Senator Mr. Zbigniew Cichoń; Assistant Director of the Department of Regional Policy of the Marshal Office of the Lesser Poland Region Mr. Jacek Woźniak; Deputy Chairman of the Krakow City Council Ms. Małgorzata Jantos; Director of the Branch of Pedagogical Oversight Mr. Wincenty Janowiak, also representing the Lesser Poland Curator of Education; Rector of the Jagiellonian University Prof. Wojciech Nowak; Rector of the Krakow University of Economics Prof. Andrzej Chochół; Prorector for Educaton at the AGH University of Science and Technology Prof. Andrzej Tytko; Prorector of the University of Agriculture Prof. Florian Gambuś; Prorector for Student Matters of the Pedagogical University of Krakow Prof. Jan Suchanicz; Prorector for Student Matters of the Krakow University of Technology Prof. Leszek Mikulski; Rector of the Andrzej Frycz Modrzewski Krakow University Prof. Jerzy Malec; Prorector for Student Matters of the University of Physical Education in Krakow Prof. Aleksander Tyka; Prorector for Education and International Affairs of the Jan Matejko Academy of Fine Arts Prof. Piotr Bożyk; Prorector of the Ludwik Solski Academy for the Dramatic Arts Prof. Dorota Segda; Prorector for Education, Development and Cooperation of the State Higher Vocational School in Nowy Sącz Docent Dr. Marek Reichel; Dean of the Department of Physiotherapy of the University of Physical Education in Krakow Dr. Hab. Anna Marchewka; Rector of the Jesuit University of Philosophy and Education Ignatianum Rev. Prof. Henryk Pietras; Rector of the Bobolanum Pontifical Faculty of Theology Rev. Prof. Zbigniew Kubacki; Rector of the Pontifical Faculty of Theology in Wroclaw Rev. Prof. Andrzej Tomko; Prorector for Education and Development of the John Paul 
II Catholic University of Lublin Rev. Prof. Dr. Hab. Andrzej Derdziuk; Director of the Theological Institute of Częstochowa Rev. Dr. Mikołaj Węgrzyn; former Rector Rev. Prof. Dr. Hab. Adam Kubiś; former Rector Rev. Prof. Dr. Hab. Jan Dyduch; Honorary Consul of the Italian Republic Ms. Anna Boczar-Trzeciak; General Consul of the Federal Republic of Germany Mr. Werner Köhler; Consul of the Slovak Republic Mr. Tomasz Kaszaj; Representative of the Command of the Municipal Fire Service in Krakow Mr. Stanisław Nowak; Chairman Mr. Antoni Rączka; Rev. Władysław Gasidło, P.A.; Rev. Janusz Bielański, P.A.; pastor of the St. Anne's Collegiate Church Rev. Prof. Dr. Hab. Tadeusz Panuś; members of the Archdiocesan Chapter House, members of the Chapter House of St. Anne's Collegiate Church; representatives of the Krakow Archdiocesan Curia; priestdeans of the Archdiocese of Krakow; rectors of major seminaries; the directors of theological institutes connected to the university by a contract regarding cooperation; and representatives of the uniformed services, Scanmed and Bank BPH.

On this occasion, it is worth noting that members of the Polish episcopate, representatives of secular government and Polish universities and consuls sent congratulatory telegrams and letters: Cardinal Marian Jaworski; Bishop Prof. Dr. Hab. Andrzej F. Dziuba, Bishop of Łowicz and Chairman of the Scientific Council of the Polish Episcopal Conference; Archbishop Henryk Hoser, SC, Bishop of Warsaw-Praga; Rev. Dr. Piotr Bajor, Secretary of the Congregation for Catholic Education; Mr. Bronisław Komorowski, President of the Republic of Poland; Prof. Barbara Kudrycka, Minister of Science and Higher Education of the Republic of Poland; Chairman of the Conference of Polish Academic Schools Full Prof. Dr. Hab. Wiesław Banyś; Rector of the Witold Pilecki Higher Vocational State School in Oświęcim Regular Prof. Dr Hab. Witold Stankowski; Rector of the Stanisław Pigoń Higher Vocational State School in Krosno Prof. Dr. Hab. Grzegorz Przebinda; Rector of the Silesian Medical University in Katowice Dr. Hab. Reader Przemysław Jałowiecki, MD; Rector of the Wroclaw University of Economics Prof. Dr. Hab. Andrzej Gospodarowicz; Rector of the Adam Mickiewicz University in Poznan Prof. Dr. Hab. Bronisław Marciniak; Rector of the Cardinal Stefan Wyszyński University in Warsaw Rev. Dr. Hab. Stanisław Dziekoński, also professor of the Cardinal Stefan Wyszyński University in Warsaw; Rector of the Karol Marcinkowski University of Medical Science in Poznan Prof. Dr. Hab. Jacek Wysocki; Rector of the University of Szczecin Prof. Dr. Hab. Edward Włodarczyk; Rector of the University of Warmia and Mazury in Olsztyn Prof. Dr. Hab. Ryszard J. Górecki; Rector of the University of Warsaw Dr. Hab. Marcin Pałys, also a Professor of the University of Warsaw; Rector of the Medical University of Warsaw Prof. Dr. Hab. Reader Marek Krawczyk, MD; Dean of the Faculty of Theology at the Adam Mickiewicz University in Poznan Rev. Prof. Dr Hab. Jan Szpet; Voivodeship Mr. Marek Sowa; Chairman of the Lesser Poland Voivodeship Sejmik Mr. Kazimierz 
Barczyk; Director of the National Science Center Prof. Dr. Hab. Engineer Andrzej Jajszczyk; Consul of the Republic of Malta in Krakow Ms. Agnieszka Kamińska; Consul General of the Slovak Republic in Krakow Mr. Marek Lisansky.

Another important part of the inauguration was the matriculation of first-year students of the four faculties of the university: Theology, Philosophy, History and Cultural Heritage as well as the Social Sciences. Rev. Prof. Dr. Hab. Maciej Ostrowski, the Prorector, led this part of the ceremonies. As was the custom in previous years, after the matriculation the Chairperson of the Students' Union Ms. Oliwia Topolska gave a speech encouraging her youngest colleagues to take the most advantage of the time of their studies and to become active in the Students' Union.

After the matriculation, there was the giving of awards to academic staff, the authors of the best dissertations and for university administrators. Seventeen persons received the Rector's Award for achievement in scientific-didactic and organizational work, while two persons received an award for the best doctoral dissertation, seven received an award for the best Master of Arts dissertation and five persons received an award for the best professional Bachelor of Arts dissertation. Eleven persons received the Rector's Award for university administrators.

The last part of the ceremony was the inaugural lecture titled "Ethics and Politics", which was given by Archbishop Jean-Louis Bruguès, Archivist and Librarian of the Holy Roman Church and former Secretary of the Congregation for Catholic Education. Referring to the analogy of the intertwined relationship between ethics and politics, the archbishop noted that politics has conquered ethics, espousing "liberty, equality and brotherhood" as its slogan. As a result of this, "under the pretext of introducing equality between individuals and societies, politics [...] has imposed the absolute law of the stronger one: the iron law of the market, when the dubious 'invisible hand' determined the concurrences of interests, or also the right of nationalisms, which is all the more brutal and has inspired the bloodiest wars in the history of our continent..." As the most ethical of these values, brotherhood could not accommodate politics, because "we would have to evoke the person of the father so that people could recognize brothers among themselves. However, the father was killed in 1793, having been guillotined among his own people [...]. The Supreme Being never felt any fatherly sensitivity," Archbishop Bruguès summarized.

The entirety of the inaugural ceremony was accompanied by the singing of Psalmodia, the choir of the Pontifical University of John Paul II, under the direction of Włodzimierz Siedlik. At the beginning of the inauguration, the choir sang "Psalm 150" and "Gaude Mater Polonia", followed by "Gloria" (G. Track) and "Gaudeamus igitur". At the conclusion of the ceremony, the choir performed Charles Gounod's "Laudate Dominum". 
Another very important event in the life of not just our university but also of the city of Krakow were the Eighth Days of John Paul II (November 5th-7th 2013), whose theme was "Wisdom", because the late pope made generous use of the wisdom contained in Divine revelation, and his life is witness to great wisdom. This event is a common initiative of the Council of Rectors of Krakow Universities. They are of an academic, interdisciplinary, popularizing and cultural nature. They serve as the inspiration for undertaking academic research whose aim is the popularization of the pope's heritage. Because of the memorial of St. Charles Borromeo, John Paul II's patron, as well as the anniversary of the latter's ordination, they occur at the beginning of November each year. This year, the Days of John Paul II took place in the facilities of several universities belonging to the aforementioned council. As in the previous year, the honorary patrons of the event were: Cardinal Stanisław Dziwisz, Archbishop of Krakow; Cardinal Franciszek Macharski, Archbishop Emeritus of Krakow; Mr. Jerzy Miller, Voivode of Lesser Poland; Mr. Marek Sowa, Marshal of the Lesser Poland Voivodeship; and Mr. Jacek Majchrowski, Mayor of the city of Krakow.

The Days of John Paul II included the following academic sessions: Oblicza mądrości 313 - 2013. Z czego wyrastamy, ku czemu zmierzamy" ("The Faces of Wisdom 313 - 2013: What We Grow Out of and Where We Are Going") organized by the Fides et Ratio International Academic Society (November 4th 2013); (Muzyka wobec poezji i nauczania Karola Wojtyły i Jana Pawła II" ("Music in Lieu of the Poetry and Teachings of Karol Wojtyła and John Paul II, Part IV") organized by the Academy of Music in Krakow; "Research and Wisdom" organized by the Jesuit University of Philosophy and Education Ignatianum (November 5th 2013); and a meeting with George Weigel titled: "John Paul II: A Doctor of the Church?" organized by the Academy of Music in Krakow (November 6th 2013).

The central academic event of the Days of John Paul was the international symposium "Oblicze mądrości" ("Faces of Wisdom”), which took place on Thursday November 7th 2013 in the auditorium of the Collegium Novum of the Jagiellonian University. The lectures were devoted to such matters as: "Mądrość w świetle wiary" ("Wisdom in Light of Faith", Cardinal Zenon Grocholewski); " Wisdom Has Built Her House"": The Church in Defense of Reason (Mr. George Weigel); "Autorytet i dialog: Jana Pawła II droga do mądrości" ("Authority and Dialogue: John Paul II's Road to Wisdom", Rev. Prof. Dr. Hab. Andrzej Szostak); "Mądrość nie jest posiadaniem odpowiedzi, ale wyleczeniem niedostatków mowy" "Wisdom Is Not Having All the Answers, But a Remedy for the Scarcity of Speech", Rev. Prof. Dr. Hab. Zdziwsław Kijas, OFMConv); "Mądrość w polityce. Mądrość polityka" ("Wisdom in Politics: The Wisdom of the Politician", Dr. Hab. Zdzisław Ryn); "Mądrość wiary" ("The Wisdom of Faith", Prof. Dr. Hab. Andrzej Białas); "Mądrość Jana Pawła II jako drogowskaz przy kreowaniu techniki służącej dobrym 
celom" "“The Wisdom of John Paul II As a Compass the Creation of Technology Serving Noble Purposes", Prof. Dr. Hab. Ryszard Tadeusiewicz).

Furthermore, there were many other cultural events, including literary and photographical contests for works inspired by the thought and output of Karol Wojtyła/John Paul II aimed at students from all over Poland. The awards were given after Mass at the Have No Fear! John Paul II Center in Krakow-Łagiewniki at the conclusion of the Days of John Paul II. Analogous days were organized in Tarnow and Krosno. ${ }^{1}$

Each month, open lectures related to the subject matter of Pope John Paul II's teaching are organized in concern for preserving and handing down the legacy of John Paul II to the young generation. They are organized by the Center for Studying the Thought of John Paul II. In the past academic year, the following lectures were given by the representatives of various academic and cultural milieus: "O Matce Odkupiciela" (“About the Mother of Our Redeemer", Rev. Rev. Hab. Bogusław Kochaniewicz, OP, Professor at the Adam Mickiewicz University in Poznan); "Dlaczego Polacy nie przyjęli nauczania Jana Pawła II?" ("Why Did the Poles Not Accept the Teachings of John Paul II?", Dr. Krzysztof Mazur, Jagiellonian University, Krakow); "Jan Paweł II o męczennikach” (“John Paul II About the Martyrs", Rev. Dr. Witali Siarko, Krakow); "Mesjanizm Jana Pawła II" ("The Messianism of John Paul II", Dr. Paweł Rojek, Jagiellonian University, Krakow); ““'Diakonia prawdy” jako ważne zadanie społeczne według encykliki Jana Pawła II „Fides et ratio"” ("The 'Diaconate of Truth' As an Important Social Task According to John Paul II's Encyclical Fides et Ratio", Rev. Prof. Dr. Hab. Tadeusz Borutka, Pontifical University of John Paul II, Krakow); “Co zostało z pontyfikatu Jana Pawła II? , ("What Remains of the Pontificate of John Paul II?”, Rev. Dr. Maciej Zięba, OP, Tertio Millennio Institute, Krakow); "Praktyczne wyzwania personalizmu Wojtyły" ("The Practical Challenge of Wojtyła's Personalism", Dr. Hab. Ryszard Stocki, Professor of University of Social Sciences and Humanities, Wojtyła Institute, Krakow); "Wojtyła i Tischner o wolności" ("Wojtyła and Tischner About Freedom", Dr. Inga Mizdrak, Krakow University of Economics).

The center also organizes a discussion session about John Paul II's new feminism titled: "kobieta21" ("woman21"). The meetings occur once a month, and participants of the discussion session have a blog: www.kobieta21.salon24.pl.

The center also publishes the "Studia nad myślą Jana Pawła II" "Studies on the Thought of John Paul II") editorial series, whose editor is Rev. Prof. Dr. Hab. Jarosław Kupczak, OP. It recently published two volumes. Volume XIV contains the study Pojęcie milczenia i jego funkcja w relacji między Bogiem i czlowiekiem

${ }^{1}$ You can gain more information (in Polish) under the following address: http://www.jp2.krakow. pl/_2013/index.php. 
w homiliach Jana Pawta II ("The Concept of Silence and Its Function in the Relationship Between God and Man in the Homilies of John Paul II") by Rev. Paweł Gabara, Krakow, The Pontifical University of John Paul II in Krakow Press, 2013), and Volume XV contains the study Solidarność w nauczaniu Jana Pawła II: Znaczenie pryncypium $w$ świetle encyklik spotecznych ("Solidarity in the Teaching of John Paul II: The Meaning of the Principle in Light of His Social Encyclicals"), Krakow, The Pontifical University of John Paul II in Krakow Press, 2014.

Krakow boasts not only John Paul II, but also Rev. Prof. Józef Tischner, a philosopher well-known both in Poland and in Europe. The Tischner Days serve the aim of the popularization of his philosophical and social-political thinking. They are organized by the Pontifical University of John Paul II, the Jagiellonian University (this year's main organizer), the Ludwik Solski Academy for the Dramatic Arts and the "Znak" Publishing House. Cardinal Stanisław Dziwisz is the honorary patron.

The Most Recent 15th Tischner Days, which took place on April 23rd26th 2014 under the motto "Odwaga myślenia" ("The Courage to Think"). The Tischner Days began with a Mass led by Bishop Prof. Dr. Hab. Grzegorz Ryś in St. Anne's Collegiate Church. Next, there was a ceremony for the giving of the Józef Tischner Znak and Hestia Award. This year's Tischner Days included a scientific session titled: "Między sceptycyzmem a nadzieją. Wokół myśli Leszka Kołakowskiego i Józefa Tischnera" ("Between Skepticism and Hope: Concerning the Thought of Leszek Kołakowski and Józef Tischner"); a discussion meeting of the "Philosophers' Cave" titled: "Co znaczy odważnie myśleć?" "“"What Does it Mean to Think Boldly?"); and a lecture from the Colloquia Tischneriana series titled: "Myślenie jest rzeczą groźną" ("Thinking Is a Dangerous Thing") given by Prof. Chantal Delsol from the Académie française. The lecture took place on Thursday April 23rd 2014 in the Auditorium Maximum of the Jagiellonian University. The professor noted that independent thinking gives birth to a threat everywhere and always; noteworthy examples from antiquity were the cases of Antigone and Socrates. Thinking freely is related to responsibility, which means openness to truth, which also requires courage. St. Augustine had already noted this in his Confessions, in which he said that people "love truth when she shines on them, and hate her when she rebukes them" (Book X, 23). For this reason courageous thinking can lead one to isolation. According to Prof. Delsol, individualism in responsible thinking is increasingly rare because of the dominant holistic thinking, which in fact is group thinking.

A particularly important anniversary was that of the creation (erection) of the Faculty of Theology in Krakow on January 11th 1397. Its central point was the promotion to academic degrees. The anniversary ceremonies took place on January 11th 2014. The university gave thanks to God for 617 years of providence 
over the faculty by a ceremonious Mass, which the university's Grand Chancellor Cardinal Stanisław Dziwisz celebrated in the Wawel Cathedral. Rev. Dr. Hab. Ireneusz Stolarczyk, a professor of the Pontifical University of John Paul II and Dean of the Faculty of Theology Section in Tarnow, gave the homily. After Mass, there was a promotion ceremony, during which 14 persons (11 at the Faculty of Theology, one at the Faculty of History and Cultural Heritage and two at the Faculty of Theology Section in Tarnow) received doctoral diplomas. Meanwhile, six persons received the diploma of a habilitated doctor: Rev. Dr. Hab. Marcin Godawa, Dr. Hab. Marek Kita, Rev. Dr. Hab. Józef Pochwat, MS, Rev. Dr. Hab. Jacek Siewiora and Rev. Dr. Hab Antoni Świerczek at the Faculty of Theology; and Dr. Hab. Joanna Mysona Byrska at the Faculty of Philosophy. The following received professors' diplomas (which recognized that the person in question received the academic title of a Professor): Rev. Prof. Dr. Hab. Władysław Zuziak (Professor of the Humanities) and Rev. Prof. Dr. Hab. Wojciech Zyzak (Professor of Theology). Meanwhile, the following became Full Professors: Prof. Dr. Hab. Juliusz Chrościcki and Rev. Prof. Dr. Hab. Tomasz Rozkrut. Rev. Prof. Dr. Hab. Wojciech Zyzak, Dean of the Faculty of Theology, expressed gratitude on behalf of those who were promoted.

The second promotions, which hitherto had taken place on the memorial of St. Stanislaus, Bishop and Martyr (May 8th), this year for the first time took place on Monday June 9th 2014 in the Wawel Cathedral in connection with the liturgical memorial of St. Hedwig the Queen (June 8th). They were also an occasion to remember the anniversary of the erection of the university (then the Pontifical Academy of Theology) by Pope John Paul II (on December 8th 1981) and raising it to the rank of a pontifical university by Pope Benedict XVI (on June 19th 2009). The aforementioned promotions took place after ceremonious Vespers about St. Hedwig the Queen, which were prepared by sisters from the Congregation of the Sisters of St. Queen Hedwig and were led by the university's Grand Chancellor Cardinal Stanisław Dziwisz. Fourteen persons received doctoral diplomas (five at the Faculty of Theology, five at the Faculty of Philosophy and four at the Faculty of History and Cultural Heritage). Five persons received the diploma of habilitated doctor: Rev. Dr Hab. Cezary Smuniewski at the Faculty of Theology; Dr. Hab. Piotr Augustyniak and Dr. Hab. Zdzisława Kobylińska at the Faculty of Philosopy; Sr. Dr. Hab. Susi Ferfoglia, whose habilitation thesis was done at the Krakow Music Academy; and Rev. Dr. Hab. Robert Kantor, whose habilitation thesis was done at the Cardinal Stefan Wyszyński University in Warsaw, at the Faculty of Theology Section in Tarnow). Rev. Prof. Dr. Hab. Wiesław Przyczyna received the academic title of Professor of Theology. He also expressed his gratitude to Cardinal Dziwisz and the university in the name of those who were promoted. 
Cooperation with research centers abroad exercises enormous influence on the development of the university. Particularly lively are academic contacts with centers in Bochum, Ružomberok, Prešov, Kyiv and Lviv. Evidence of constantly growing cooperation was the signing of a new agreement of cooperation between our university and El Instituto de Filosofia "Edith Stein" ("Institute of Philosophy 'Edith Stein"') in Granada, Spain, which took place on January 15th 2014 in the Bishop's Palace in Krakow. As a result of this agreement, the students of the institute will be able to receive graduation diplomas at the Faculty of Theology of our university, and our professors will also give lectures there. Archbishop Javier Martinez, Archbishop of Granada, and Cardinal Stanisław Dziwisz, Archbishop of Krakow, participated in the signing of this agreement.

The University also takes part in the European Union's ERASMUS+ program, which has replaced the terminated LLP Erasmus program (Lifelong Learning Programme ERASMUS). In December 2013, the university received a new Erasmus University Charter, which gives us the right to request funds related to the mobility of students and staff until the 2020-2021 academic year. As part of the Erasmus program, a total of 44 agreements with 30 foreign universities were signed in the 2013-2014 academic year. They were the following universities: Albert-LudwigsUniversität Freiburg (Germany); Universite de Fribourg (Switzerland); University of Prešov in Prešov (Slovakia); Ostravska univerzita v Ostrave (Czech Republic); Univerzita Karlova v Praze (Czech Republic); Universidad de Navarra (Spain); Univerza v Ljubljani (Slovenia); Katolicka Univerzita v Ruzomberku (Slovakia); Universita degli Studi di Verona (Italy); Universita degli Studi di Trento (Italy); Vilniaus Universitetas (Lithuania); Theologische Fakultat Trier (Germany); Univerzita Komenskeho v Bratislave (Slovakia); Universita Cattolica del Sacro Cuore (Italy); Ruhr-Universitaet Bochum (Germany); Pontifical University, St. Patrick's College Maynooth (Ireland); The University of Malta (Malta); KU Leuven (Belgium); Universidade Catolica Portuguesa (Portugal); Universidad Complutense de Madrid (Spain); Westfaelische Wilhelms-Universitaet Muenster (Germany); Univerzita Konstantina Filozofa v Nitre (Slovakia); The Newman Institute (Sweden); Katholische Hochschule Nordrhein-Westfalen (Germany); Vilniaus Universitetas (Lithuania); Philosophisch-Theologische Hochschule Sankt Georgen Frankfurt am Main (Germany); Universitaet Bonn (Germany); Universidade Catolica Portuguesa (Portugal); University of Limerick (Ireland); Trnava University in Trnava (Slovakia); Institute of Tourism Studies (Malta); Kaunas University of Technology (Lithuania).

As part of the Erasmus program, in the 2013-2014 academic year 12 of our students went abroad to a partner university for part of their studies; 14 students from various universities visited us as part of this exchange; 18 of our students completed a professional internship abroad; 14 academic staff members gave 
lectures at foreign partner universities; and one lecturer from abroad gave lectures at our university (in Church music). Furthermore, 17 staff members took advantage of training visits.

The aforementioned cooperation with Bochum, particularly the Faculty of Catholic Theology at the Ruhr-Universität Bochum, which has been uninterrupted since the signing of an agreement on November 2nd 1982. It consisted of an exchange organized in such a way that during the autumn of each year professors (typically two) travelled to Bochum, while each spring professors from Bohum came to Krakow. In 1997, students of both universities began to participate in the exchange program. Rev. Prof. Christof Breitsameter is responsible for the organization of these meetings from the German side, while Rev. Dr. Hab. Jan Dziedzic is responsible from our side. In relation to the 30th anniversary of the cooperation, the German side organized a conference at the university in Bochum, which took place on May 13th 2013. Our Rector Rev. Prof. Dr. Hab. Władysław Zuziak as well as Rev. Dr. Hab. Jan Dziedzic and a group of a dozen or so students represented our university. During the conference, the following gave speeches: Prof. Elmar W. Weiler, Rector of Ruhr-Universität Bochum; Prof. Wilhelm Damberg, Associate Dean of the Faculty of Theology in Bochum; as well as Rev. Prof. Władysław Zuziak, Rector of the Pontifical University of John Paul II. Over 100 persons took part in the conference. As part of last year's exchange, the German side took part in an academic conference organized from the initiative of the Chair of Pastoral Theology of the Faculty of Catholic Theology titled: "Starość: problem czy szansa?" (“Old Age: A Problem, or an Opportunity?") on May 15th 2014, which will be discussed below. Prof. Dr. Hab. Bernhard Grümme gave a speech during the conference.

Meanwhile, an expression of the university's openness to academic collaboration east of Poland's borders is the tightening of bonds between the university and the Catholic academic milieu in Lviv. This is expressed in the university Senate's December 16th 2013 decision, which expressed consent to prepare an agreement of academic cooperation between the Faculty of Theology and the Major Seminary of the Archdiocese of Lviv in the Latin Rite in Lviv-Bryukhovychi. The project of this agreement was presented to the Congregation for Catholic Education for approval. It is an agreement analogous to affiliation agreements signed with major seminaries in Poland. A specific sign of this cooperation in the past academic year was an academic symposium connected to the inauguration of the academic year in the St. Joseph Bilczewski Theological Institute and the aforementioned seminary, which took place on October 18th 2013. The topic of the symposium was: "Uniwersytet jako miejsce spotkania nauk" ("The University As a Place Where the Sciences Meet"). Rev. Prof. Dr. Hab. Józef Wołczański of the Faculty of History and Cultural Heritage, who gave a lecture titled: "Wydział Teologiczny 
Uniwersytetu Jana Kazimierza we Lwowie 1918-1939 i jego kontynuacja" ("The Faculty of Theology of the John II Casimir University in Lviv in 1918-1939 and Its Continuation"), represented our university.

In the context of the cooperation with Church universities, it is also worth mentioning the university's engagement in the forum of secular universities. Our university maintains regular contacts with all the universities in Poland through its participation in the Conference of Rectors of Universities in Poland (CRUP). Since March 4th 2006, in accordance with z $\$ 2$ of the updated Rulebook, the Rector of the Pontifical University of John Paul II is a member of this conference.

Another expression of full participation in university life is also the practice of giving honorary doctorates, which is a form of promoting academic achievements and particular merits in the development of knowledge undertaken by specific persons. In the past academic year, the Faculty of Philosophy bestowed an honorary doctorate upon Prof. Lorenzo Ornaghi of Italy on October 10th 2013 in the Collegium Maius auditorium of the Jagiellonian University. Prof. Ornaghi is an accomplished journalist and political scientist who for many years served as Rector of the Catholic University of Sacro Cuore in Milan (2002-2012) and as the Minister of Heritage and Cultural Activities of the Italian Republic in the government of Mario Monti (2011-2013). He received this title because of his promotion of universal Christian values in European social and political life, contribution to protecting European cultural heritage, rich academic output in the fields of the social and political sciences, kindness towards and support of the Pontifical University of John Paul II and engagement in developing the cooperation between the Pontifical University of John Paul II in Krakow of the Catholic University of the Sacred Heart in Milan. The reviewer of Prof. Orhaghi's output was Rev. Prof. Dr. Hab. Stanisław Pamuła, and the laudatory was Rev. Prof. Dr. Hab. Janusz Mastalski, Dean of the Faculty of Social Sciences. In his lectio magistralis, the recipient of the honorary doctorate spoke of the relevance and livelihood of Catholic Social Teaching in the age of late secularization. He noticed that answers to the serious issues of the deepening anxieties of our age "could be given - at least to a certain degree - by the relevance and livelihood of [Catholic] social teaching, that would at least somewhat influence the improvement of social, economic and cultural life, which will remain empty if there is a lack of the direct engagement of Catholics in the area of politics." Therefore, in his opinion, there is an urgent need for there "to appear a 'new generation of Catholics engaged in politics', which Pope Benedict XVI asked for in his speech to the participants of the general congregation of the Pontifical Council for the Laity in 2008, in the various centers where contemporary politics are organized and created."

Our university not only expresses its recognition of other academic milieus by giving honorary doctorates, but the university itself is held in high esteem. In 
the past academic year, two of our professors receive honorary doctorates. Prof. Dr. Hab. Walery Pisarek of the Faculty of Social Sciences received an honorary doctorate at the Jan Kochanowski University in Kielce. The ceremony of bestowing upon him this honorary degree took place on June 5th 2014. In his laudation, Prof. Dr. Hab. Marek Ruszkowski emphasized that Prof. Pisarek enjoys an unblemished moral opinion and is a master for several generations of Polish philologists and journalists. He also remembered the rule according to which "the study of effective use of language should begin with learning how to be silent. He who does not learn to be silent should not speak at all, because sooner or later he will ?napyta biedy sobie albo innym?" (from the book Stowa między ludźmi, "Words Between People", 1985). A second distinguished staff member of our university is Rev. Prof. Dr. Hab. Michał Heller, who received an honorary doctorate from the University of Life Sciences in Lublin in recogntition of his achievements and merits, given to him "in particular as an outstanding philosopher of nature, cosmologist, mathematician, physician and theologian; a world-renowned author of academic works in which through a philosophical critique of the empirical sphere he searches for bridges between science and religion." The ceremony took place on June 17th 2014. In his laudation, Prof. Dr. Hab. Krzysztof Kowalczyk, Dean of the Faculty of Agrobioengineering in Lublin, emphasized that perhaps "his greatest contribution to both Polish and international culture and science is his constant making us aware that science, that great adventure of mankind, has its limits." In the conclusion of his lecture devoted to freedom and change, the recipient of the honorary doctorate said: "the problems of change, time and human freedom are not reduced solely to our more or less subjective speculations, but are essentially tied to the deep structure of our Universe."

An international event of great significance was the "Rola Kościoła katolickiego w procesie integracji europejskiej" ("Role of the Catholic Church in the Process of European Integration") conference organized for the fifteenth time by the Pontifical University of John Paul II. It took place in the Krakow Conference Center in Tomaszowice near Krakow on September 26th-27th 2014. It was devoted to the topic: "Co nas łączy, co nas dzieli w Europie?" "What Binds Us Together and What Divides Us in Europe?"). The conference was organized with the cooperation of the Robert Schuman Foundation in Luxembourg, the Konrad Adenauer Foundation in collaboration with the European People's Party (Christian Democrats) in the European Parliament, the Commission of the Bishops' Conferences of the European Union (COMECE) in Brussels and the Wokół nas ("Concerning Us") publishing house in Gliwice.

Cardinal Stanisław Dziwisz, Archbishop of Krakow, inaugurated the conference. After him, the guests were greeted by Bishop Tadeusz Pieronek (Chairman 
of the organizational committee), Mr. Marek Sowa (Marshal of the Lesser Poland Voivodeship), Dr. Jan Olbrycht (Member of the European Parliament and Chairman of the Polish delegation in the European Parliament), Dr. Christian Schmitz (Director of the Konrad Adenauer Foundation in Poland) and Mr. Horst Langes (Honorary Chairman of the Robert Schuman Foundation in Luxembourg).

The introductory remarks were devoted to the following problems: "Migrations and Their Consequences for Europe" (Archbishop Dr. Francesco Montenegro, Archbishop of Agrigento), "Społeczna Gospodarka Rynkowa - odpowiedź na kryzys?" ("The Social Market Economy: A Solution to the Crisis?", Ms. Flaminia Giovanelli, Under-Secretary for the Pontifical Council for Justice and Peace) and "Młode pokolenie - między niepewną przyszłością a stabilnością" ("The Young Generation: Between an Uncertain Future and Stability", Dr. Cezary Kościelniak, Adam Mickiewicz University in Poznan). Next, there were discussions in three thematic groups respectively to the topics of the introductory speeches. In the First Group, the discussions were led by Rev. Dr. Leszek Gęsiak, SJ (Vatican Radio); in the Second Group, they were led by Rev. Dr. Maciej Zięba, OP (Director of the Tertio Millennio Institute in Krakow); in the Third Group by Mr. Przemysław R. Röhrenschef (Vice-President of the School for Leaders Foundation in Warsaw). In the evening, Mass was concelebrated for the participants of the conference at the Sanctuary of St. John Paul II in Krakow-Łagiewniki. Cardinal Stanisław Dziwisz celebrated the Mass and Archbishop Wojciech Polak, Primate of Poland, gave the homily.

On the second day of the conference in Tomaszowice, the results of the discussion in the working groups were presented. Next, Prof. Adam Daniel Rotfeld (Co-Chairman of the Polish-Russian Group for Difficult Matters) gave a speech introducing the discussion about the next topic: "Nowe otwarcie dla Europy" ("A New Opening for Europe"). At the conclusion of the entire conference, the Rector of our university, Rev. Prof. Dr. Hab. Wojciech Zyzak, spoke. He noted that looking at the discussed problems from the perspective of faith creates a new space allowing "for the engagement in the transformation of the world and the entry into dialogue with everyone for whom the good of the fatherland is important with greater liberty and in the horizon of the new meaning".

The popularization of concern for the unity of Christians is among the main duties of the Institute of Fundamental Theology, Ecumenism and Dialogue. For this reason, each year the institute actively takes part in the organization of the Week of Prayer for Christian Unity and the related Day of Judaism in the Catholic Church and Day of Islam in the Catholic Church. Thus in the past year, the institute was the co-organizer of the aforementioned Week of Prayer for Christian Unity, which in Krakow took place on January 19th-26th 2014. The main theme of the week were the words of St. Paul: Is Christ divided?" (1 Corynthians 1:13). 
The co-organizers of the week were also the Krakow branch of the Polish Ecumenical Council and the Ecumenical Ministry of the Archdiocese of Krakow. Ecumenical services of the Word of God took place in various churches and chapels belonging to the Roman Catholic, Orthodox, Lutheran, Methodist, Polish National Catholic and Mariavite Churches. The inauguration ceremony of the Week of Prayer for Christian Unity took place in the Orthodox church on 24 Szpitalna Street in Krakow on Sunday January 19th 2014. Rev. Paweł Kubani, a representative of the Roman Catholic Church, gave the introduction to a common prayer. Meanwhile, the Week of Prayer for Christian Unity ended with a Mass and ecumenical service led by Bishop Grzegorz Ryś, which took place on Sunday January 26th 2014 in the Dominican Holy Trinity Basilica in Krakow on 12 Stolarska Street. During the service, Rev. Adam Kleszczyński, a representative of the Evangelical Methodist Church, gave a speech concluding the service.

Meanwhile, the Eighteenth Day of Judaism in the Catholic Church in Poland took place earlier than the Week of Prayer for Christian Unity, on January 16th 2014 in all of Poland under the motto "The Lord is my strength [...]; he has become my salvation" (Exodus 15:2). The Institute of Fundamental Theology, Ecumenism and Dialogue of the Pontifical University of John Paul II and the Ecumenical Ministry of the Archdiocese of Krakow organized it. The prayer meeting took place in the Franciscan Basilica under the direction of Bishop Grzegorz Ryś, who also preached the Word of God. Naturally, representatives of the Jewish community and of various Christian communities took part. The singing of the Perfugium early music ensemble enriched the prayer. After the service, the participants of the meeting took part in a conference given by Rabbi Avi Baumol of the Jewish community in Krakow's Kazimierz district. The conference took place in the Pontifical University of John Paul II in Krakow, and its subject was the question: “Mojżesz - łączy nas czy dzieli?" ("Moses: Does He Unite or Divide Us?"). Rabbi Baumol emphasized Moses' leadership qualities, which are evident in the fact that he "leads, judges and acts. We can consider this to be the essence of the spirit of a true leader". This is also an example for us.

Meanwhile, the celebrations of the Fifteenth Day of Islam in the Catholic Church in Poland in Krakow took place on January 30th 2014. Their motto was the words: "Expanding Mutual Respect Through Education". The Institute of Fundamental Theology, Ecumenism and Dialogue of the Pontifical University of John Paul II in Krakow, the Ecumenical Ministry and the Franciscan Order organized them. The celebrations began with a service in the Franciscan basilica and were led by Bishop Grzegorz Ryś in the company of Rev. Roman Banasik (the Franciscans' guardian) and Rev. Prof. Dr. Hab. Łukasz Kamykowski (Lecturer of the Ecumenical Ministry of the Archdiocese of Krakow and Director of the Institute of Fundamental Theology, Ecumenism and Dialogue of the Pontifical University 
of John Paul II in Krakow). The participants of the prayer included: Asaad Sultan Hachim Abu Galal, Ambassador of Iraq in Poland; Ziyad Raoof, Plenipotentiary of the Kurdistan Regional Government; Hayssam Obeidat, Chairman of the Muslim Community in Krakow and Lecturer at the Jagiellonian University; Rev. Prof. Władysław Zuziak, Rector of the Pontifical University of John Paul II in Krakow; Ms. Agata Skowron-Nalborczyk, Deputy Chairperson of the Common Council of Catholics and Muslims (the only such institution in Europe); the Little Sisters of Jesus (a congregation inspired by the life and writings of Blessed Charles de Foucald), representatives of the Krakow Club of Catholic Intellectuals and the Znak milieu as well as other lay Catholics. The Perfugium early music ensemble accompanied the prayer. After the prayer in the auditorium of the Pontifical University of John Paul II in Krakow, there was a discussion panel that sought an answer to the question: "Dlaczego powinniśmy wiedzieć więcej o islamie?" ("Why Should We Know More About Islam?"). The panel included Dr. Hab. Agata SkowronNalborczyk, a specialist in Oriental Studies at the University of Warsaw; Ms. Agata Marek, Chairperson of the "Vox Humana" association, which promotes knowledge about the methods of preventing and countering discrimination and what is broadly recognized as social discrimination; Sr. Anna Pawłowska, ZDCh, a teacher of religion; and Mr. Erdem Agaslan, a Turkish Muslim studying in Germany.

In addition to the aforementioned cyclical events, there are also symposia, conferences and guest lectures that serve to deepen the knowledge passed down in the classroom. They are also a means of popularizing the results of the research that certain academic faculty of our university undertake. Some of them were organized with the participation of institutions external to the university. Below are some of them.

As an initiative of the Chair of Pastoral Theology at the Faculty of Theology with the cooperation of the Greek-Catholic Theological Faculty at the University of Prešov, the Twenty-First International "Sacrum and Nature" Seminar titled "Ekoturystyka" ("Ecotourism"), which took part on September 27th-28th 2013 in Prešov, Slovakia. The presented speeches concerned such topics as: tourism that is friendly towards man, the diversity of tourism and agro-tourism and its influence on man's moral profile, the psychological aspects of tourism; education for agro-tourism and environmental protection in the media, eco-tourism in Slovakia as a form of knowing spiritual heritage, ethics, ecology, tourism, and eco-tourism in the Slovak wilderness and its specificity. The materials were published in a book (both in Polish and in Slovak): Ekoturistika. XXI. medzinárodná vedecká konferencia «Sacrum a Priroda», Eds. P. Tirpák, J. Dziedzic, PrešovVysoké Tatry 2013, pp. 118.

On the occasion of the fiftieth anniversary of the ratification of the Second Vatican Council's constitution about the liturgy, Sacrosanctum Concilium, which 
inaugurated the renewal of the Church's liturgical life, there was organized another, fourth international meeting of liturgical theologians as part of the "Ad fontes liturgicos" series titled: "Liturgical Reforms and the Return to the Sources". The symposium took place on October 23rd-24th 2013 and was organized by the Liturgy Institute of the Pontifical University of John Paul II, the Greek-Catholic Theological Faculty in Prešov (Slovakia) and the Ukrainian Catholic University and the Ukrainian Liturgical Center in Lviv (Ukraine). The symposium was devoted to studies on liturgical reforms in the Western Church and the Eastern Churches, in particular such matters as: the ideal of liturgical reform in the twentieth century, liturgical renewal in the Orthodox liturgy, the Second Vatican Council's liturgical reform of the Mass as an attempt to return to the origins as well as matters related to the reform introduced by the Second Vatican Council, reforms undertaken in the past, local traditions and also the perspective of future reforms. The representatives of academia from eight European countries took part. Materials from the symposium were published as: Reformy liturgii a powrót do źródet ("Reform of the Liturgy and the Return to the Origins", Eds. J. Mieczkowski, P. Nowakowski CM, Krakow 2014, pp. 397 (Series: Ad Fontes Liturgicos).

Given the current demographic crisis, studies on the family are particularly valuable. The answers to the needs of the contemporary family were sought during the conference titled: "Współczesna rodzina: perspektywy lokalne i europejskie" ("The Contemporary Family: Local and European Perspectives"), which took place on October 23rd-24th 2013 and was organized by the Faculty of Theology Section in Tarnow in cooperation with the Faculty of Social Sciences at the Pontifical University of John Paul II in Krakow, the Faculty for Studies on the Family at the Cardinal Stefan Wyszyński University, the Catholic Theological Faculty at Charles University in Prague and the Faculty of Theology at the University of Ljubljana.

The subject matter discussed during the conference included such matters as the Church's stance towards the family, the threats that the contemporary family faces and the place of the family in society from an international perspective. Also discussed were such matters as disability, pathologies, functioning in social-cultural structures and the question of the development of studies on the family as an academic discipline, the perspective of the education of specialists, research methodology and the educational challenges resulting from other areas of academic, cultural and social studies. The materials from the conference as well as additional studies concerning phenomena related to the area of studies on the family, especially the methodology of the discipline, were presented in two publication in the new "Nauki o rodzinie" (Family Studies) published by The Pontifical University of John Paul II in Krakow Press (Nauki o rodzinie w stużbie rodziny ("Family Stidies in the Service of the Family"), Ed. J. Stala, Krakow [2014], 
pp. 623; The Contemporary Family: Local and European Perspectives, red. E. Osewska, J. Stala, Krakow 2015, pp. 338).

Ethics has great importance in both business and socio-political activity, although not infrequently it is ignored. In order to search for answers to contemporary ethical problems, the Chair in Ethics along with the Chair in Social and Political Philosophy of the Faculty of Philosophy organized the sixth academic conference in the "Etyka i życie publiczne" ("Ethics and Public Life") cycle. Its topic was: "Zaufanie a życie publiczne" ("Trust and Public Life") and took place on October 29th-30th 2013. Academic staff from Polish, Slovak and German universities gave lectures. During the conference, such phenomena as the anthropological basis for trust, the concept of trust and the phenomenon of mistrust, the various aspects (institutional, political-legal, commercial, media and ecological) of trust, the credibility of commercials (particularly pharmaceutical ones), media manipulations, trust in post-modernity, trust as a fundament of social communication, trust at the foundations of solidarity in the teaching of John Paul II, trust of medical staff, trust in the family and many other interesting matters. Materials from this conference are available in the publication: Zaufanie $w$ życiu publicznym ("Trust in Public Life"), Eds. W. Zuziak, J. Mysona Byrska, Krakow 2014, pp. 353.

The meeting with Cardinal Zenon Grocholewski, which took place in the Rectorate on Friday November 8th 2013, was importance with regards to the connection with the Holy See. The representatives of the Pontifical University of John Paul II in Krakow met with the cardinal, the prefect of the Congregation for Catholic Education who came to Krakow to give a speech during the Eighth Days of John Paul II. The meeting's participants included rectors, deans, associate deans and the directors of institutes. During the discussions, the cardinal familiarized himself with the situation of each faculty and shared his reflections on the situation and role of Catholic universities. He heeded particular attention to the issue of the university's adaptation to the requirements resulting from the implementation of the Bologna Process.

Presently, a concordat regulates Church-state relations. Legal problems related to its functioning were the subject of the symposium titled: "Czy polski konkordat faworyzuje Kościół katolicki?" ("Does the Polish Concordat Favor the Catholic Church?"). It took place on November 14th 2013 and was organized by the Institute of Canon Law (presently, the Faculty of Canon Law). The issues discussed in the speeches concerned the following problems: the teaching of religion - the provisions of the Concordat and Polish legislation, the meaning of the rule of the independence and autonomy of Church and state, Concordat marriages - an evaluation from the perspective of 15 years since the Concordat's regulations came into effect, the recognition of Church corporations - practical problems, chaplaincy in the military and other uniformed services, the perspective of changes in the financing of 
the Catholic Church in Poland in light of Article 22 of the Concordat and the activity of the Concordat committees. The symposium was complemented by the ceremony of a special tome to Rev. Prof. Dr. Hab. Józef Krzywda, CM, titled: Servabo legem tuam in toto corde meo. Ksiega pamiatkowa dedykowana księdzu profesorowi Józefowi Krzywdzie CM, dyrektorowi Instytutu Prawa Kanonicznego UPJPII z okazji 70. rocznicy urodzin ("With All My Heart I Will Serve Thy Law: A Special Tome Dedicated to Rev. Prof. Józef Krzywda, CM, Director of the Institute of Canon Law of the Pontifical University of John Paul II on His Seventieth Birthday"), Eds. A. Zakręta, A. Sosnowski, Krakow 2013, pp. 674.

Political matters were also the topic of reflection in an entirely different milieu of researchers. The Institute of History of the Faculty of History and Cultural Heritage organized an interdisciplinary international academic conference about "Tekst polityczny w historii kultury Europy Środkowej i Wschodniej" ("The Political Text in the History of Central and Eastern Europe"), which took place on November 14th-16th 2013. Academic staff from Polish, Russian, Ukrainian, Lithuanian and Belarusian universities gave speech. During 15 sessions (each with three speeches), various texts of a political nature that are significant for Central and Eastern Europe were analyzed. During the first two plenary session, there were presented: the "drunken" speeches of Joseph Stalin as political text, the texts of the founders of the revolution in Romania in 1989, two speeches of Lech Kaczyński on the 70th anniversary of the outbreak of World War II, the contradiction between Politics and administration in a presidential text (for example, the speeches of Ms. Dalia Grybauskaite, President of Lithuania), the superlative in the contemporary Russian political text (based on presidential speeches during the crisis of 2008-2009) and the political speeches of Alexander Lukashenka - rhetorical ideals and techniques. During the following parallel session, many specific matters such as, for example, agitational speeches, the semantics of a specific speech and the programs of political parties or the political use of poetry or meaning of certain letters (such as that from Khomeini to Gorbachev) were dealt with. The subject of analysis and discussion was thus the political text in all its aspects and genres, from the political manifesto, to the speech, political program, legal act, political journalism to visual and audiovisual documentation. It above all intended to show the political text in the aspect of its influence and cultural dependencies, which undoubtedly helps to understand many political events.

The search for that which links interdenominational and interreligious dialogue was the subject of the "Miłosierdzie Boże - miłosierdzie ludzkie" ("Divine Mercy: Human Mercy") conference organized by the Institute of Fundamental Theology, Ecumenism and Dialogue at the Pontifical University of John Paul II in Krakow and the Krakow branch of the Polish Ecumenical Council. The conference took place on November 19th 2013, when the image of mercy from Orthodox, 
Augsburg Evangelical Lutheran, Mariative, Jewish, Islamic, Buddhist and, of course, Catholic perspectives was presented. Speeches concerned the following phenomena: mercy in the doctrine of Catholic theology, Divine mercy in the liturgical texts of the Trodion postny, mercy and charity from the Evangelical perspective, the evolution of Christian views on Divine mercy over the span of cultural eras, mercy as an attribute of the Absolute, mercy in Judaism, mercy in Islam and loving mercy and compassion as the main message of Mahayana Buddhism.

Interreligious studies were the subject of another academic conference, the Second International Religious Studies Symposium titled: "Religie: pola badawcze, metody i perspektywy" ("Religions: Fields of Research, Methods and Perspectives") organized in conjunction with the Jagiellonian University, which took place on November 25th-27th 2013 at the campus of our university. Speeches were mostly given in English, but also in Polish and in Russian. During the fourteenth session, the following phenomena were presented and discussed: The Thesis of the Common Core in Mysticism, Politics, and Polarization; "The Liberation of Religiosity from Religion": G. Simmel's Concept of Emotional Origins of Religion; Religious Freedom As Disconnecting Catholic Integralism and Tolerance; Religious Commercialism and Its Cannibalization of the Mainstream Expression; Faith As Relation: Sociological Perspective; Priming religion: What Can It Tell Us about Religious Prosociality?; Anthropology of the Body and Religious Studies: Reflections from the Research of the Bengali Vaishnava Sahajiya Tradition; The Feminist Approach to the Study of Buddhism: Some Remarks; Various Forms of Jewish Female Head Covering in the Kingdom of Poland: (Ortho) Praxis, Cultural Battles and Debates; Catharism - Invented Heresy? The Continuity of the Christian Dualist Tradition in the Middle Ages, Narratives about the Beginnings of Cathar Groups: Historical Accounts or Polemical Fantasies; Religious Identity of the Individual against the Paradigm of Sensations Society; The Context of Modern Sociological Theory: Myth as Eternal Philosophy in the Conditions of the Desecularization of Society; The Moon and the Opossum: Australian Imagery of Sacrum; Can We Talk about Prayer Outside of Christianity? The Problem with the Existence of Prayer in Pagan Rome; The Issue of Religious Identity in Early Modern Times: Prince Ostrogski's Case; The Sacralization of Loci and Localization of Social Status in the Urban Orthodox Cathedrals; The Church in the Media Sphere of the Post-Secular Society: The Dialectic of Real and Virtual; Issues of Religion in Media Studies: Methodological Features; Religiosity As an Object of Modern Ukrainian Religious Studies Discourse; Assimilation in American Life: An Empirical Assessment of Milton Gordon's Multidimensional Theory; Redefining the Culture, Reimaging the Self: Iranian Converts to Christianity in the Pahlavi Period; A Multidimensional Approach to the Study of Religiosity: Some Reflections on an Inquiry of Pentecostal churches in Russia; "Smolensk Religion": 
Between Popular and Civil Religion; Material Religion: Aesthetic and Semiotic Approaches to the Study of Ritual; Far Eastern Dragons: Between Mythology and Everyday Life; An Introduction to the Study of the Indian Concept of Purușa within the Cognitive Paradigm; The Specificity of Working with Patients with Ecclesiogenic Neurosis; Mindfulness As a Neuro-Psycho-Biological Attempt to Define the Phenomenon of Spirituality; Suffering Capital - The Capital of Grace: Religious Grounds of Community in Laski; The Pastoral Letters of Primates and the Polish Bishops in Comparison with the Official Language of the Ruling Political Elites (1945-1956); Linguistic Implications of Religious Elements in the Esoteric; Who's Talking? The Question about the Narratives in the Context of Religious Pluralism; Possession - A Psychiatric Approach; Religious Delusions in the Case of Schizophrenic Psychoses; Can Religiosity Be a Compulsion? The Connection between Faith and Obsessive-Compulsive Disorder; and The Philosophy of Religion As a Way to Skepticism.

The period of the half-century since the Second Vatican Council's issuing of a decree on the mass media was an occasion for academic reflection about the heritage, challenges and further development of Church teaching about social communications. The forum for such a reflection was a conference titled: "50 lat dekretu Soboru Watykańskiego II «Inter mirifica»: dziedzictwo i perspektywy" ("50 Years of the Second Vatican Council's Decree: Inter mirifica: Heritage and Perspectives"). It took place on December 5th 2013 and was organized by the Institute of Journalism and Social Communications. During the conference, the following problems were discussed: The Media As a Divine Gift for Building the Human Community, Fifty Years after Inter mirifica: The Polish Experience, The Change of Pontificates: Challenges and Opportunities for the Holy See, Fifty Years After Inter mirifica: New Challenges, Inter mirifica's Unrecognized Postulate, Information in the Service of Mankind from the Perspective of Inter mirifica, Are Catholic Media a Means for Evangelization? Pre-Evangelization and PostEvangelization, Conciliar Concern for the Human Face of the Media, Witness of Faith or the Propagation of Piety? What the Authors of Inter mirifica Desired.

Somewhat more distant history was the subject of a conference organized by the Chair of East-Central European History of the Nineteenth and Twentieth Centuries as well as the Foundation for the Culture and Heritage of Polish Armenians. Its subject was: "Arcybiskup Józef Teofil Teodorowicz (1864-1938). Pasterz Kościoła ormiańskiego w Polsce, mąż stanu, kaznodzieja, pisarz" (“Archbishop Józef Teofil Teodorowicz [1864-1938]: A Pastor of the Armenian Church in Poland, Statesman, Preacher and Writer"). The conference took place on December 6th7th 2013 and was part of the "Week of Memory About Józef Teodorowicz, an Armenian Archbishop and Polish Patriot". Academic staff from our university, the Jagiellonian University, Adam Mickiewicz University in Poznan and the Lviv 
National Academy of Arts presented the results of their research. The topics of the speeches included such phenomena as "The Teodorowicz Affair, or Archbishop Józef Teodorowicz's mission to the Vatican Concerning Upper Silesia, his patriotic preaching and his commentary to Pope St. Pius X's encyclical Poloniae Populum issued on December 12th 1905.

After a decided critique of religion by certain contemporary philosophers, it would seem that the philosophical discourse about God has lost its significance. Meanwhile, it gave the impulse for the search for new answers to accusations made by Friedrich Nietzsche, Sam Harris and Michael Shermer. The conference "Mistrzowie podejrzeń - negacja, afirmacja czy przezwyciężenie?" ("The Masters of Suspicion: Negation, Affirmation or Conquest?") organized by the Chair of the Philosophy of God and the Chair of the Philosophy of Religion in collaboration with the Stanisław Staszic AGH University of Science and Technology in Krakow. It took place on December 19th-20th 2013 on the campus of the AGH University of Science and Technology. During the five sessions, the following were among the discussed phenomena: Mistrust of Faith: A Discussion with Nihilism and Axiology; The Strategies of Religious Thinking: Between Conservatism and Post-Secularism; Communism As a Reassessment of All Values? Marx, Spinoza, Deleuze; The Legacy of the Masters of Suspicion in the New Atheism; and Feminist Theology: A Mild or Radical Hermeneutics of Suspicion? The speakers frequently referred to the philosophical legacy of Friedrich Nietzsche and also to Marxist and neo-Marxist currents of social critique, undertaking an attempt to evaluate them critically.

An important event that influenced the development of didactics in the area of the media was the opening of a new television studio, which is located in the university building at 1 Franciszkańska Street. Cardinal Stanisław Dziwisz led the blessing ceremony on January 22th 2014. The television studio was the initiative of the Institute of Journalism and Social Communications, which is part of the Faculty of Social Sciences. The creation and professional furnishing of the television studio was possible thanks to many persons and the financing from the European Regional Development Fund as part of the Lesser Poland Regional Operational Program in the years 2007-2013. Our students of journalism and social communications will be able to participate in television workshops in this studio as part of their coursework in the following specializations: journalism as well as radio-television production. Thanks to this, students will gain practical skills related to the preparation of television programs in the field of the logistics of a journalist's work.

The language of the symbol has great significance in our culture. Thus it is with recognition that we should accept academic research related to the hermeneutics of the symbol, which became the subject of the Fourth International Academic 
Conference from the "Symbol - Znak - Rytuał" ("Symbol - Sign - Ritual") cycle titled: "Od narodzin do śmierci" ("From Birth Until Death"). The conference was organized by the Chair of Auxiliary Sciences of History and Archival Science at the Faculty of History and Cultural Heritage and took place on January 29th 2014 at the main library of the Pontifical University of John Paul II in Krakow at 10 Bobrzyńskiego Street. Papers were presented by academic staff of our university, the Greek-Catholic Theological Faculty at the University of Prešov in Slovakia, the Faculty of Fine Arts and Model Manufacture at the University of Nyíregyháza (Hungary), the Polish Academy of Sciences, the Agricultural University of Krakow, the Tischner European University in Krakow, the Witelon University of Applied Sciences in Legnica and the John Paul II Catholic University of Lublin.

The papers dealt with such phenomena as: Birth and Death As Historiographic Metaphors; The Symbolism of Trees in Wedding Ceremonies and Courtship; GreekCatholics and the Deportation of Jews from Slovakia During the Second World War; Jewish Religious Rituals and the Life Cycle of Man; The Sign, Symbol and Ritual of Initiation in the Sacraments of the Eastern Catholic Churches; Marriage: Customs, Traditions, Symbols; The Present Traits of Media Education for Youth; "From 'Memento Mori' to 'Totenkopf': The Symbol of the Skull with a Particular Emphasis on Germany Military Formations; The Meaning of Christian Prayer for the Dead; The Symbolism of the Night, Which Becomes the Beginning...; The Headless Horseman: The Fragments of the Thematic Discourse in Zygmunt Haput; and Symbolism in Art. The papers have been collected and published in the book: Znak. Symbol. Rytuat. Od narodzin do śmierci ("Sign - Symbol - Ritual: From Birth to Death"), Eds. J. Marecki, L. Rotter, Krakow: Wydawnictwo Pasaże 2014, pp. 270.

"Beauty" is not among the categories used very frequently in theological language. Thus the fact that phenomena in the field of aesthetics were the subject of academic research is all the more worth noting. The Chair of Ecclesiology of the Faculty of Theology at the Pontifical University of John Paul II in Krakow and the Committee on Theological Sciences at the Polish Academy of Sciences in cooperation with the Jagiellonian University organized an academic conference titled: "Kościół jest piękny" ("The Church Is Beautiful"), which took place on February 2nd 2014. During the conference, the following phenomena were presented: The Hidden and Apparent Beauty of the Church, Medieval Thinking About the Church Expressed in the Architectural Beauty of Cathedrals, The Beauty of the Pluralism of the Eastern Churches, The of the Liturgy of the Eastern and Western Churches, The Wisdom of Catholic Education and The Asthetics and Transcendence of Christian Culture. The results of the research presented at the conference have been published under the title: Piękno Kościoła, Eds. M. Chojnacki, OCist, J. Morawa, A. Napiórkowski OSPPE, Krakow: The Pontifical University of John Paul II in Krakow Press, 2014, pp. 210. 
Although not directly, the beauty of the Church is revealed through the spirituality of the communities that form it. Last year, the spirituality of monasteries was popularized in the most recent edition of the symposium devoted to this matter. The eighth symposium in the cycle titled: "Duchowość Klasztorów Polskich: Przekaz i komunikacja" ("The Spirituality of Polish Monasteries: Message and Communication") was devoted to the spirituality of Rev. Semenenko and had the title: "Wokół «Dziennika» Piotra Semenenki" ("Concerning Piotr Semenenko's Diary"). It took place on March 12th 2014 and was organized by the Chair of Spirituality of the Media and Social Relations that are part of the Institute of Journalism and Social Communications and the Polish Province of the Congregation of the Resurrection of Our Lord Jesus Christ. The papers dealt with such matters as: The Priest and Spirituality with Regards to Social Life; The Dynamism of Mystical Life Based on Rev. Piotr Semenenko's Diary; The Literary Diversity and Unity of the Theological Ideal in Rev. Piotr Semenenko's Mystical Writings; Contacts Between Rev. Prokop Leszczyński, OFMCap, and Rev. Piotr Semenenko; The Presence of Philosophy in the Diary of Rev. Piotr Semenenko, CR; and Elements of Antropology in the Diary of Rev. Piotr Semenenko, CR. Materials from the symposium have been published in the volume: Wokót "Dziennika» o. Piotra Semenenki, red. W. Mleczko CR, Krakow: St. John Paul II Publishing House, 2014, pp. 162.

The Inter-Congregational Institute for Catechesis in Krakow, led by the Ursulines of the Roman Union, took part in the popularization of anthropological theology by organizing the Forty-Fourth Catechetical Symposium, whose theme was: "Człowiek w planie Boga" ("Man in God's Plan"). The symposium took place on March 22nd 2014. Papers were given by professors from our university as well as the John Paul II Catholic University of Lublin and the Major Seminary of the Order of Capuchin Friars Minor in Krakow. They dealt with such matters as: the relationship between freedom, truth and conscience; the psychological dimension of religious life; the role of sexuality in relations between men and women; and how to discuss sexuality with children and youths. There are plans to publish the materials from the symposium.

The years-old and rich activity of the Inter-Congregational Institute for Catechesis in its present form (since 1950) was, unfortunately, annulled by a decree of Archbishop of Krakow Cardinal Stanisław Dziwisz on June 27th 2014 (nr. 1673/2014) due to a motion of the Prioress General of the Ursulines of the Roman Union. The main reason for this decision was a significant decline in the number of candidates for studies offered by the institute. Consequently, the agreement signed on March 1st 1993 between the Pontifical University of John Paul II in Krakow (then the Pontifical Academy of Theology) and the Inter-Congregational Institute for Catechesis in Krakow, as a result of which the university the institute 
was a unit organized by the university, became null. This means that on September 30th 2014 the studies offered by this institute (in all the forms of education) were closed. In a motion from September 9th 2014, the University Senate accepted the current state of affairs.

The teaching of the Second Vatican Council was an especially important reference point for Pope John Paul II. A Polish-German academic seminar about "Teologia pastoralna po II Soborze Watykańskim. Duszpasterskie założenia i koncepcje. Porównanie polsko-niemieckie w kontekście współczesności” ("Pastoral Theology After the Second Vatican Council: The Assumptions and Concepts for the Ministry. A Polish-German Comparison in the Context of Modernity"), which took place on April 1st-4th 2014 in St. Peter (Germany), was held. It made up the second part of the academic seminar, which took place in 2013 in Krakow. The Chair of Religious Communication of our university as well as the Chair of Pastoral Theology at the Albert Ludwig University of Freiburg organized it. Undergraduate and graduate students from the Pontifical University of John Paul II and the Albert Ludwig University of Freiburg took part in it. During the seminar, the following phenomena (each first from the Polish perspective, and then from the German perspective) were undertaken: The New Evangelization; The Activity of the Polish Group for the New Evangelization; The Cooperation of the Catholic and Orthodox Churches; Forms of Family Ministry; The Engagement of the Church in the Activity of the Mass Media; The Integration of Immigrants with Parish Communities; The Post-Conciliar Development of Specialist Ministry; The Main Currents in Homiletics After the Second Vatican Council; The Role of Permanent Deacons; Respect for the Sacred and the Laity's Engagement in the Liturgy; and The Catechumenate of Adults. The seminar's participants valued its merit and organization very highly.

The efficiency of all academic research is contingent on their methodology. For this reason, the Copernicus Center for Interdisciplinary Studies organizes a conference devoted to methodology. The Eighteenth Krakow Methodological Conference was devoted to "The Limits of Physics and Cosmology" and took place on May 8th-9th 2014 at the Polish Academy of Arts and Sciences in Krakow. Lectures were in English, and their subjects were the following: Metacosmology and the Limits of Science; Uncertainties and Impossibilities in Cosmology; Bounds on Physics and Cosmology; Exploring the Limits of Space-Time; Unweaving the Fabric of the Universe; Noncommutativity and Singularities; Noncommutative Geometry, Lorentzian Structures and Causality; On the Use Noncommutative Geometry and its Relation to General Relativity; Probing the Dark Energy; Simplicity in Cosmology; Recovering Gravity Theory from Cosmological Observations?; Conformal Standard Model; Are the Singularities Limits of Cosmology?; The Limits of Mathematical Notation; Field of Rationality and Category Theory. 
Lecturers represented the following research centers: the Copernicus Center for Interdisciplinary Studies, Jagiellonian University, University of Milan, Queen Mary University of London, University of Szczecin, University of Warsaw, Université de Paris-Sud 11, Nicolaus Copernicus University and the Pontifical University of John Paul II in Krakow.

The university serves not only young students, but it also tries to fulfill the needs of elderly persons. An expression of this concern is the organization of an international academic conference titled: "Starość: Problem czy szansa?" ("Old Age: A Problem, or an Opportunity?"). The conference took place on May 15th 2014 and its organizers were the Chair of Pastoral Theology of the Faculty of Theology at our university along with our University of the Third Age and the Ruhr Universität Bochum (Germany). During the conference, the following phenomena were presented: Old Age in the Bible; The Church and Old Age: A PastoralTheological Perspective; The Challenges of Ministry for Elderly Persons; The Psychological-Existential Aspects of Old Age; The Pensions System and Policy with Regards to a Shrinking Population; "Not Only Crocheting and Bingo": Old Age As a Religious-Pedagogical Challenge ("Nicht nur Häkeln und BingoSpielen. Das Alter als religionspädagogische Herausforderung" [B. Grümme]). The presented papers were published in the book titled: Starość: problem czy szansa? Refleksja pastoralnoteologiczna ("Old Age: A Problem, or an Opportunity? A Pastoral-Theological Reflection"), Ed. J. Dziedzic, Krakow: The Pontifical University of John Paul II in Krakow Press, 2015, pp. 252.

For several centuries, our Faculty of Theology was part of the Jagiellonian University. Its 650th anniversary was an opportunity to recall shared history. On May 14th 2014, there was an academic session titled: "Wkład Wydziału Teologicznego w dzieje Uniwersytetu Jagiellońskiego" ("The Contribution of the Faculty of Theology in the History of the Jagiellonian University"), which was organized by our university. It was devoted to illustrious persons in the history of the Faculty of Theology during the times when it was part of the Jagiellonian University and which had special significance for the history of the entire university. During the session, the following persons and contribution to history were presented: Fundamental Values in the Thought of Paweł Włodkowic; Rev. Sebastian Jan Piskorski: A Zealous Promoter of Divine Praise; Rev. Stefan Pawlicki: A University Type; Bishop Józef Sebastian Pelczar: A Professor and Saint; Novelties in the Academic Work of Rev. Prof. Aleksy Klawka; Karol Wojtyła at the Jagiellonian University: Polish and Theological Studies.

The significant influence of the media on public life causes ethical matters to play a key role in its functioning. For this reason, the studies on these phenomena and the popularization of their results allow us to nurture hope for the increase in the respect for the rules of ethics in the media. In response to these expectations, 
our university's Institute of Journalism and Social Communications along with the Axiology of Communication Section of the Polish Social Communications Association organized the Eighth International Conference "Etyka mediów" ("The Ethics of the Media") titled: "Dialog w mediach - media w dialogu" ("Dialogue in the Media, Media in Dialogue"). The conference took place on May 15th-16th 2014. During the conference, 57 papers were presented. Two plenary sessions were devoted to the following phenomena: "Dialog w mediach" ("Dialogue in the Media") and "Media w dialogu" ("The Media in Dialogue"). Meanwhile, the thematic sessions focused on such phenomena as: The Rational Basis of Dialogue; Dialogue in the Media As a Value; Dialogue in the New Media; Dialogue in Media Cultures; The Language of Dialogue in the Media; Journalistic Dialogue; Dialogue in Public Relations and Advertising; and The Search for Media Forms of Dialogue. Among the interesting examples noted during the conference, it is worth noting that according to statistics, Pope Francis enjoys a record-high number of mentions in the worldwide internet (over 49 million each month), which leads to the popularization of not only himself, but also of his teaching. There are plans to publish the materials from this conference.

Pilgrimages and religious tourism are a new area of research and studies developed at our university in cooperation with foreign universities. For this reason, there was organized an academic conference titled: "Pielgrzymowanie i turystyka religijna" ("Pilgrimages and Religious Tourism"), which took place on May 21st 2014. It was organized by the Chair of Pastoral Theology and was an international seminar. Academic staff and graduate students from Germany (Albert University of Freiburg [Albert-Ludwigs-Universität Freiburg]), France (the University of Strasbourg [Université de Strasbourg]), the Czech Republic, the Jagiellonian University (Institute of Geography and Spatial Management) and our university. During the conference, a unique mosaic of pilgrimages was presented. The topics discussed at the conference included: A Critical View of Pilgrimages As an Inspiration for Pilgrims' Chaplaincy; The Theology of Pilgrimages and Its Biblical Basis; Pilgrimages in Poland; Pilgrimages As a Method of the New Evangelization in Light of a Crisis of Faith; The Way of St. James in Poland; The Marian shrine in Szczyrk; and The Sanctuary of the Holy Cross in Mogiła.

Studies on the links between religion and the culture of a given nation allow for the better understanding of its history and its particular thinkers. The academic conference "Religion and Culture in Russian Thought", organized by the Copernicus Center for Interdisciplinary Studies, the Instituto de Filosofía Edith Stein in Granada (Spain), Centro Internacional Estudio Oriente Cristiano and the Science and Culture Creators Association EPISTEME. The conference took place on May 29th-30th 2014 and was devoted to the search for answers to the following questions: What, According to Russian Thinkers, Is the Connection 
Between Christianity and Philosophy, Art, Science and Politics Like?; What Is the Difference in the Approach to Culture in Eastern and Western Christianity?; and What Is the Current Stance of Orthodoxy Towards the Contemporary World? The essence of the answers to these questions was sought in three research areas stated by philosophy, theology and fiction. During the conference, 53 papers - whose authors were academic staff from universities in Poland, Russia, England, Sweden, Germany, Holland, Spain, Italy, Austria, Lithuania, Belarus, Ukraine, Slovakia, the Czech Republic and the United States - were presented. The speakers discussed phenomena such as The Critique of Secular Renaissance Culture by Nikolai Berdyaev; Catastrophism As a Manifestation of the "Crisis of Consciousness" in Polish and Russian Culture; The Relation Between Philosophy and Religion in the Orthodox Tradition; The Relationship Between Knowledge and Faith, Philosophy and Theology As Conceived by Georges Florosky; The Theological Output of Russian Émigrés Looking for a Synthesis of the Russian Theological Legacy with Contemporary Western Theology; The Relevance of the Debate Between Athens and Jerusalem in Russian Philosophy; The Rationality of Polish Messianism from the Perspective of Human Nature; History and Social Order with Respect to the Thought of Zygmunt Krasiński and Vladimir Solovyov; The Religious Universalism of Siemion Frank and the Christian Concept of Love; Moral Justification Through Religion That Gives Meaning to Consciousness, Power and Divine Truth; The Politicization of the Religious Idea of the Antichrist in Russia After the Transformation of 1989; The Necessity of Christianizing Contemporary Culture; Defeating Secularization by Referring to Christianity; and The Ethical Aspects of the Concept of "Holy Rus" in the Contemporary Teaching of the Orthodox Church. The result of this conference is the publication: Religion and Culture in Russian Thought: Philosophical, Theological and Literary Perspectives, ed. T. Obolevitch, P. Rojek, Krakow: The Pontifical University of John Paul II in Krakow Press, 2014, pp. 190.

Naturally, the life and legacy of Pope St. John Paul II is particularly inspiring for our university. Familiarization with his spirituality and its popularization were the subject of an academic session titled: "Duchowość świętego Jana Pawła II" ("The Spirituality of St. John Paul II"). It was organized by the Institute of Spirituality of the Faculty of Theology and took place on June 12th 2014. The papers concerned such concepts as: The Concept of Religious Life in the Teaching of Pope St. John Paul II; Vocation in the "Autumn of Life" According to Pope St. John Paul II; The Main Currents of Spirituality in the Private Diaries of Pope St. John Paul II; The Way to Spiritual Freedom in the Teaching and Witness of Pope St. John Paul II; The Spirituality of Mercy in the Teaching of Pope St. John Paul II; The Spirituality of Consecrated Life in the Documents of Pope St. John Paul II; Pope St. John Paul II on the Spirituality of the Laity; and The Sacredness of the 
Human Person in the Teaching of Pope St. John Paul II. This session later turned out to be a good preparation for the celebration of the Year of Consecrated Life.

The witness and spirituality of other saints is also inspiring. The particular aspect of religious life that is going on a pilgrimage was the topic of the next conference from the "Święci i błogosławieni na «Drodze św. Jakuba»" ("Saints and Blesseds on the Way of St. James") cycle was organized by the Pontifical University of John Paul II in Krakow, the Faculty of Geography of the Commission of National Education Pedagogical University of Krakow and the parish and Confraternity of St. James in Krakow-Więcłąwice Stare. The conference took place on September 6th-7th 2014 in Krakow-Więcławice Stare, and its topic for this year was: "On the 800th Anniversary of St. Francis of Assisi's Pilgrimage to Santiago de Compostela". Many interesting papers presenting from diverse perspectives phenomena such as: Whether or Not St. Francis Prayed at the Tomb of St. James and Concerning the First Franciscans Who Made Pilgrimages to Santiago de Compostela; What Was the Historical Background of St. Francis of Assisi's Pilgrimage to Santiago de Compostela?; Devotion to St. Roch in the Polish and European Traditions; Why Did St. Brigid of Sweden Make a Pilgrimage to Santiago (1341-1342)?; The Spanish Pilgrimage of Jakub Sobieski to Santiago; Is San Andrés de Teixido a Competitor to Santiago? The Bridge between the East and the West; Velehrad As a Place of Renewed Pilgrimage Tradition and the Development of Pilgrimage Routes; Saints at the Tomb of St. James the Apostles: Meditations on the Porta Itineris Sancti Iacobi in Santiago de Compostela; The Polish Apostle of Northern Europe: St. Hyacinth "of the Pierogies" on the Mazovian Way of St. James; St. James Versus St. Martin: A Debate About the Indulgence in Ciernia; Mendicant Monasteries a Place of Rest for Pilgrims in the Italian Part of "Via Francigena"; Two Medieval Musical Relics on the Way to Santiago: What St. Francis Could Have Sung During His Pilgrimage to Compostela; The Role of the Lesser Poland Tourist Information System in the Development of Pilgrimage Tourism in the Lesser Poland Voivodeship; The Way of St. James in Northeastern Mazovia and Podlachia As an Element of European Cultural and Historical Heritage; The Way of St. James in Western Pomerania, Rugia, Mecklenburg and Eastern Holstein; The Opening of the Way of St. James in Dubrovnik in 2014; The Way of St. James on the Polish-Slovak Border: The Present State and the Perspectives of Development; Koreans on the Camino de Santiago; Los peregrinos in the Context of the Changes in the Contemporary World; The Way of St. James in Poland in the Opinion of Pilgrims and Tourists; The Way of St. James Via Regia in the Subcarpathian Voivodeship in the Consciousness of Its Inhabitants; A Lesson of Humility on the Camino Eight Centuries After St. Francis in the Eyes of an Almost-Atheist; The Virtue of Humility, One of the Fundaments of the Franciscan Rule - A Model for Pilgrims and Societies; The Lazy Spaniard and a Rebel without a Cause: Saints 
in the Mazovian Way of St. James; The Pilgrimage on the Way of St. James to the Canonization of Two Popes: John XXIII and John Paul II; and St. James on Stove Tiles - The Decoration of a Stove, or Symptoms of Devotion? The conference will undoubtedly lead to the growth of devotion to St. James.

At a time of high unemployment, the dignity of work is among the most cherished values. Thus it is worth noting the first conference about work and fork work, which was titled Labor omnia vincit ("Work Conquers All"). The conference took place on June 14th 2014 at the Stanisław Staszic AGH University of Science and Technology in Krakow, and its organizers were: the Stanisław Staszic AGH University of Science and Technology in Krakow, the Pontifical University of John Paul II in Krakow, the "Talent" Ministry for Entrepreneurs and Employers, the "Talitha Cum" Foundation and the Regional Labor Office in Krakow. The topics of the conference focused beyond the financial dimension of work, instead focusing on the spiritual, psychological and social dimensions. This conference was the response of the Christian academic and business milieus to such negative phenomena such as: unemployment, the objectifying treatment of employees, the depreciation of the value of work, the "rat race", the demoralization of employees and employers, the helplessness of young people at the labor market and the crisis situation of specialists aged over 50. The main aim of the conference was to bring back the dignity of work, heed attention to non-material values and show exemplary stances towards the challenges of the contemporary labor market. The conference was directed towards such social groups as: entrepreneurs and employers, human resources managers, those employed in administration and regional governments, academic staff, students, pedagogues, career counselors, the employees of Labor Offices and Social Aid Centers as well as those interested in the topic of work.

In addition to symposia and conferences organized by institutions that deal with didactic and research activities, it is worth noting the Mysterium fascinans academic symposium, which was linked to a beautiful celebration of the liturgy organized previously by students of theology belonging to the Liturgical Academic Circle of the Major Seminary of the Archdiocese of Krakow in collaboration with the Dominican Liturgical Center in Krakow and the Faculty of Theology of our university. Last year's Sixth Mysterium fascinans Liturgical Retreat had the motto: "Our health is in His wounds: The sacraments of healing". They were organized by the Dominican Liturgical Center foundation and took place on September 12th-14th 2014 in Krakow. The subject of reflection was the sacraments of healing, or reconciliation and penance as well as the anointing of the sick.

The dissemination of knowledge among elderly persons is the aim of the institution known as the University of the Third Age. Currently, there are more than 100 such institutions in Poland. In the 2011-2012 academic year, the University 
of the Third Age inaugurated its activity at the Pontifical University of John Paul II in Krakow. Its first director was Rev. Dr. Hab. Jan Dziedzic. The educational offerings of the university are directed towards retirees and annuitants as well as to persons over the age of 50. Classes take place on Mondays and Tuesdays and deal with topics related to: philosophy, theology, history and the social sciences. The program also includes days of reflection, formation retreats, cultural events and the visiting of heritage sites related to Christian culture. In the past academic year, 460 persons studied in this program.

May the conclusion of this presentation of the activity of our university in the past academic year be information about the cycle of meetings titled: "Ich Areopag wiary" ("Their Areopag of Faith"). These are meetings with widely known persons who have the courage to publicly speak about their faith and are organized by the seminarians of the Major Seminary of the Archdiocese of Krakow, who simultaneously are students of the Faculty of Theology. As part of this cycle, on March 19th 2014 there was a meeting with Przemysław Babiarz, a journalist and sports commentator. He is not embarrassed to openly speak about Christ and about the fact that he draws inspiration from faith in Him.

The second such meeting took place on May 14th 2014. The guests were the brothers Łukasz and Paweł Golec. They are musicians who come from the Żywiec area. They founded the musical group "Golec uOrkiestra" and play goral music with their own lyrics and in their own arrangements. They are famous and popular across all of Poland. During the meeting, they confessed that prayer was always something natural to them and a power transmitted to them from their parents. For this reason the family is also one of the most important values for them. Seminarians and students of Journalism and Social Communications organized the meeting with them.

A form of academic exchange and inter-university cooperation are also guest lectures. In the past academic year, it is worth noting the cycle of lectures by Prof. Tomas Sodeika from Vilnius titled "Mistyka a fenomenologia" ("Mysticism and Phenomenology"). These lectures took place on May 26th-28th 2014 at the Dominican College of Philosophy and Theology in Krakow. The lecturer presented a phenomenological interpretation of the Saints Bonaventure, Thomas Aquinas and Ignatius Loyola, and also Meister Eckhart. The cycle of lectures was organized by the Dominican College of Philosophy and Theology and the Chair in the Philosophy of Religion of the Faculty of Philosophy of the Pontifical University of John Paul II in Krakow.

We feel great joy and satisfaction because of the recognition that both our entire university and its individual staff have been shown by various institutions. An expression of such recognition in the international arena is the participation of our rector in the conference "The Bounds of Ethics in a Globalized World", 
which took place on January 6th-9th 2014 in Bangalore (India). The representatives of research institutions from many countries took part. Special guests were His Holiness the Dalai Lama and His Eminence Cardinal Baselios Cleemis Thottunkal. His Magnificence Rev. Prof. Dr. Hab. Władysław Zuziak gave a speech titled: "Ecological Challenges for Ethics".

It is with joy that we learned that our scientific-didactic staff member Rev. Prof. Dr. Hab. Roman Pindel, the head of the Chair of Biblical Hermeneutics and Judaism, became the new bishop of the Diocese of Bielsko-Żywiec on November 16th 2013. Meanwhile, Rev. Dr. Hab. Krzysztof Gryz, Associate Dean of the Faculty of Theology, became the Rector of the Major Seminary of the Archdiocese of Krakow on November 2nd 2013.

Another form of recognition on the international stage is state decorations. In the past year, two persons received state decorations from the hands of the President of the Republic of Poland Bronisław Komorowski. The former Rector of our university, Bishop Prof. Dr. Hab. Tadeusz Pieronek received the Commanders Cross of Polonia Restituta on May 1st 2014 for his outstanding contributions to the development and strengthening of European integration as well as special achievements in the area of state and social activity. Meanwhile, Rev. Prof. Dr. Hab. Michał Heller received the Order of the White Eagle - the oldest and highest Polish state decoration - on May 3rd 2014 "in recognition of his illustrious merits in Polish science, for his achievements in breaking down the barrier between science and religion and for his creative search for questions related to meaning, truth and beauty".

It is also worth noting that along with two persons from the Editors of Catholic Programs TVP Krakow (Ms. Joanna Adamik and Ms. Katarzyna Katarzyńska) our staff member Rev. Prof. Dr. Hab. Andrzej Baczyński received a third place award at the Twenty-Ninth International Catholic Film and Multimedia Festival Niepokalanów in 2014 for the film Podhalańska Gaździna. 50-lecie koronacji ("Podhale Sanctuary: 50th Anniversary of the Coronation") about the Sanctuary of Our Lady of Ludźmierz near Nowy Targ. A total of 158 films, music videos and television programs as well as 40 radio and multimedia programs from 23 countries took part in this festival. The creators of the film dedicated the award to the memory of Rev. Tadeusz Juchas, the custodian of the sanctuary of many years and a collaborator of the Editors of Catholic Programs TVP Krakow.

Closing the chronological description of last year's events, it is worth mentioning the results of the elections that took place near the close of the academic year in question. On September 1st 2014, a new term began for the rectoral authorities began. Rev. Prof. Dr. Hab. Wojciech Zyzak, who is a specialist in the area of the theology of the spirituality of priesthood and the laity, was elected Rector. Previously, he served as Dean of the Faculty of Theology. 
The new Prorector for Student Affairs and Didactics was Rev. Prof. Dr. Hab. Janusz Mastalski, who is a specialist in the field of pedagogy and heads the Chair of General Pedagogy at the Faculty of Social Sciences. Before his election as Prorector, he was Dean of the Faculty of Social Sciences. For several years, he has been an expert of the Polish Accreditation Committee.

Rev. Prof. Dr. Hab. Wojciech Misztal, who is a specialist in the area of the theology of spirituality and heads the Chair of Spirituality of the Media and Social Relations at the Faculty of Social Sciences, was elected Prorector for Development and Staff Policy. In the previous term, he held the function of Prorector for Development and Financial Policy.

The new Prorector for Academic Potential and International Cooperation is Rev. Prof. Dr. Hab. Józef Stala, who is a specialist in the areas of catechetics, pedagogy and education and heads the Chair of Pedagogical-Catechetical Studies at the Faculty of Theology Section in Tarnow, Editor-in-Chief of the international academic journal The Person and the Challenges and is an expert of the Polish Accreditation Committee. Previously, he served as Associate Dean for Science, Development and International Cooperation at the Faculty of Theology Section in Tarnow.

Along with the election of new rectors, some of whom previously served as Deans, there was the election of new faculty authorities. Thus until the completion of the term (until 2016), the Dean of the Faculty of Theology was Rev. Dr. Hab. Arkadiusz Baron, Professor at the Pontifical University of John Paul II in Krakow, and the new Dean at the Faculty of Social Sciences is Rev. Dr. Hab. Antoni Świerczak. Meanwhile, the Associate Dean is Dr. Hab. Małgorzata Duda.

At the start of the new term, Rev. Dr. Hab. Janusz Królikowski, a Professor at the Pontifical University of John Paul II in Krakow, was elected Dean of the Faculty of Theology Section in Tarnow. Meanwhile, Rev. Dr. Hab. Marek Kuza and Rev. Dr. Leszek Rojowski were elected Associate Deans.

We sincerely congratulate all the newly elected authorities and wish them the best in their work for the good of our university.

For a fuller picture of our university, it is worth recalling several statistics. In the 2013-2014 academic year, 3,379 undergraduate and graduate students studied at our university; 257 academic staff worked for our university (40 full professors, 76 habilitated doctors and 114 doctors as well as 27 Master of Arts recipients) and 130 remaining staff members (102 working in the administration and 28 in the library). For the first year of First Cycle studies, 463 students were admitted. In the past academic year, 209 professional Bachelor of Arts degrees, which completed the First Cycle of studies were granted (16 at the Faculty of Philosophy, 73 at the Faculty of History and Cultural Heritage and 120 at the Faculty of Social Sciences) as well as 460 Master of Arts degrees that were the capstone of Second 
Cycle studies (169 at the Faculty of Theology, 11 at the Faculty of Philosophy, 74 at the Faculty of History and Cultural Heritage, 164 at the Faculty of Social Sciences and 42 at the Faculty of Theology Section in Tarnow) and 55 Canonical Licentiates (Church degrees; 32 at the Faculty of Theology, two at the Institute of Canon Law, seven at the Faculty of Canon Law and 14 at the Faculty of Theology Section in Tarnow). Next, 26 persons received doctorates (14 at the Faculty of Theology, five at the Faculty of Philosophy, four at the Faculty of History and Cultural Heritage and three at the Faculty of Theology Section in Tarnow), 11 became habilitated doctors and six received the title of Professor.

In order to avoid misunderstandings, it is necessary to not that the above number are not always the same as those given at promotion ceremonies, because usually several months pass between the completion of an academic title (a doctorate [the publication of a dissertation], habilitation and professorship) until the promotion ceremony. For this reason, it is frequently the case that the proceeding ends in one academic year and the promotions occur in the following one.

In addition to the promotion of staff, one of the important areas of the university's activity is the promotion of its own activity. The Office of Information, which has been active since the 2004-2005 academic year, deals with this. It is through the office that the university engages in promotional activities organized for all the universities in Krakow or Poland. They include above all the Festival of Science organized by Krakow's universities. On May 21st-24th 2014 they took place for the fourteenth time in Krakow at the Main Square. Its motto was: "Science Through the Ages" and referred to the celebrations of the 650th anniversary of the Jagiellonian University. As in previous years, our university organized academic panels, painting exhibits, workshops and quizzes. Several dozen volunteers from all four faculties were engaged in the organization of our participation in the festival.

The development of modern media of social communications was made possible by the opening of an internet radio in which journalism students make practical use of the skills they have learned. Since November 19th 2010, Radio Bonus has been regularly giving internet broadcasts 24 hours a day. Its aim is the promotion of the university, its particular faculties and areas of study as well as the documentation of important events in the life of the university and Krakow. Radio Bonus cooperates with Vatican Radio, the audio service of Poland's Catholic Information Agency and domestic radio stations. Noteworthy events in the activity of the radio in the past year undoubtedly include the transmission of the ceremonies related to the canonization of Pope John Paul II. On Saturday April 26th 2014 at 8:00 PM, Radio Bonus transmitted the prayer vigil in Circo Massimo in Rome. Television screens connected Rome with the Sanctuary of Divine Mercy in Krakow-Łagiewniki, Guadelupe in Mexico, Kawekamo-Bugando in Tanzania, 
Harissa in Lebanon and Fatima in Portugal. Pope-Senior Benedict XVI was spiritually connected to those gathered at the vigil thanks to a video connection. Thanks to the kindness of the hosts at the Sanctuary of Divine Mercy in Łagiewniki, on Sunday April 27th 2014 Radio Bonus could transmit the canonization ceremony of Pope John Paul II, the patron of our university.

In addition to the radio station, a television station is also being formed. A university television station called "JP2TV" is a project realized by the university and its students as well as lecturers who work in the structures of the Institute of Journalism and Social Communication at the Faculty of Social Sciences. Both the name of the television station and the content of its programs refer to the great spiritual legacy of Pope St. John Paul II. The television station aims above all to show the depth, relevance and significance of his teachings and witness in all the areas of life. Presently, a television studio (which was mentioned above) was organized, and starting in October 2014 students and editors will be trained in technical-editorial infrastructure. The next phase of the building of JP2TV is making Television JP2TV's website with visual materials created in four editorial rooms available. The last phase will be the inauguration of the broadcasts of the television internet program live.

A particular form of the promotion of our university is its publishing activity, which The Pontifical University of John Paul II in Krakow Press deals with. The publishing house publishes research papers and academic journals. The university-wide academic journal which is regularly published since 1970 is above all Analecta Cracoviensia, which contains studies in the areas of philosophy, theology, Church history, canon law and the social sciences. Forty-two volumes (45 annual volumes) of this periodical have already been published. In addition to Analecta Cracoviensia, each faculty publishes its own journal: Polonia Sacra is the publication of the Faculty of Theology, which since 2013 also publishes the English-language magazine Theological Research: A Journal of Systematic Theology; Logos $i$ Ethos is the periodical of the Faculty of Philosophy; and Folia Historica Cracoviensia, Pro Musica Sacra (since 2004) as well as Orientalia Cristiana Cracoviensia (since 2009) are publications of the Faculty of Church History. The Faculty of Social Sciences publishes the Studia Socialia Cracoviensia (since 2009). The Institute of Canon Law publishes Annales Canonici. This is a legal annual publication directed towards academia, those who practice law and all those interested in canon law. The Faculty of Theology Section in Tarnow publishes two journals: Tarnowskie Studia Teologiczne ("Tarnow Theological Studies"; since 1938) as well as The Person and the Challenges (since 2011). The Center for Interdisciplinary Studies, which is part of the Faculty of Philosophy, publishes Zagadnienia Filozoficzne w Nauce ("Philosophical Problems in Science"). This is a biannual journal that deals with discovering and analyzing philosophical 
problems intertwined with the natural sciences. The journal Semina Scientiarum is edited by the participants of the Seminarium Naukowe z Filozofii Przyrody ("Academic Seminar about the Philospohy of Nature") and is devoted to questions at the intersection of philosophy and the natural sciences. In 2011, a new journal titled: Racjonalia. Z punktu widzenia humanistyki ("Racjonalia: From the Point of View of the Humanities") began its activity at the Faculty of Theology. It publishes the dissertations of students from the First Cycle Bachelor of Arts studies, Second Cycle Master of Arts studies Third Cycle doctoral studies, continuous Master of Arts Studies, postgraduate studies and also the academic staff of post-secondary schools. There are preparations to publish a new journal of the Faculty of Theology in the area of Biblical studies: Studia Biblica Cracoviensia.

The university's official publication of an informational nature is: Vita Academica. Biuletyn Informacyjny Uniwersytetu Papieskiego Jana Pawła II w Krakowie ("Vita Academica: The Information Bulletin of the Pontifical University of John Paul II in Krakow"), which is a bi-monthly and contains information related to the most important events at the university. Students also have their own publication: Patos. Czasopismo Spoteczno-kulturalne Młodych ("Patos: A SocialCultural Journal of the Youths"), which is edited and published by the Students' Union at our university. The magazine has been published for many years; previously, it was a quarterly, and now it is a bi-monthly. Patos is a publication of lay students, whereas men studying for the priesthood have their own magazine, Novum Tempus Liberum, which is edited by students of the Major Seminary of the Archdiocese of Krakow. Currently, it is published once a year and contains information from seminarians' seminary and student life.

Editorial series are also among the university's regular publications. It is especially worth noting Studia do dziejów Wydziatu Teologicznego ("Studies on the History of the Faculty of Theology"). Other series include: Rozprawy habilitacyjne ("Habilitation Dissertations"), Rozprawy doktorskie ("Doctoral Disserations"), Podręczniki Wydziatu Teologicznego ("Textbooks of the Faculty of Theology") as well as the series Mysterium Christi (which consists of liturgical textbooks), Studia ("Studies"; edited by the Faculty of Theology), Textus et studia and Studia nad myśla Jana Pawta II ("Studies on the Thought of John Paul II)" published by the Center for Studies on the Thought of John Paul II. The center has already published 15 volumes of the Studia.

In the 2013-2014 academic year, The Pontifical University of John Paul II in Krakow Press published 56 publications, including 19 magazines at the Vita Academica information bulletin. Among its publications, it is worth noting a book published on the occasion of the canonization of John Paul II edited by Marko Jačov, Franciszek Ziejka and Rev. Władysław Zuziak and titled Przestanie Jana Pawta II na XXI wiek ("The Message of John Paul II for the Twenty-First 
Century"; Krakow 2014, pp. 356). The publication was published along with the Polish Academy of Learning. It contains not only the authors' unique photos from meetings with John Paul II, but above all it is witness to the great richness of important truths and thoughts that are still relevant contained in his work. The publication is an expression of the conviction that the canonization of the great pope is an epochal event in the history of the Church and the world. The purpose of all the texts contained in it is the emphasizing of the relevance and livelihood of John Paul II's thought and an encouragement to further deepened studies on it.

The publishing house is systematically increasing the number of publications available online (both on the journals' websites and in the university's repository). A digital "platform of journals"2, where all the journals published by our university will eventually be made available, has been created.

In addition to didactic and research activity, the university tries to promote sacred music. This is an extension of the studies on the liturgy of the Church and its musical tradition. The Psalmodia academic choir directed by Dr. Włodzimierz Siedlik, who has been directing it since its beginning, has been at our university for 25 years. With its singing, the Psalmodia choir enhances such academic ceremonies as, for example, the ceremony of the inauguration of the academic year or the celebrations of the university's anniversary. The choir also tries to promote Polish culture abroad. Thanks to its cooperation with the St. Hedwig the Queen Foundation, it can participate in various artistic events.

In the past academic year, the Psalmodia choir celebrated the 25th anniversary of its artistic activity. The ceremonious inauguration of the anniversary began on January 19th 2014 with a concert of Christmas carols at the Basilica of the Sacred Heart of Jesus at Kopernika Street in Krakow. In addition to traditional carols, Podhale carols ("Dobrze ześ się Jezu" and "Juhaska kolynda") and one Czech carol („,Dětátko se narodilo” [Jan Josef Božan, 1719]) were performed.

In this jubilee year, the choir prepared to record the album Pater noster-Otcze nasz with the music of Romuald Twardowski (the premiere was on June 15th 2014). The choir went on a tour across Europe (in the Czech Republic, Austria and Germany) and gave concerts in Prague, Brno, Nuremburg, Munich, Salzburg and Vienna. The tour took place on December 14th-22nd 2013. It had the motto: "Poznaj mój region, poznaj mój kraj" (Get to Know My Region, Get to Know My Country). It was financed with the support of the Ministry of Culture and National Heritage.

The choir also took part in the promotion of patriotic values. An expression of this was its participation in the concert "W hołdzie Żołnierzom Wyklętym"

\footnotetext{
${ }^{2}$ http://czasopisma.upjp2.edu.pl.
} 
("An Homage to the Cursed Soldiers"), which took place on September 2nd 2014 in the Krakow Philharmonic. During the concert, music from the Czas honoru ("Days of Honor") television series and patriotic song and pieces by Wojciech Kilar were performed.

On the occasion of the canonization of John Paul II, the Psalmodia choir gave a concert consisting of choral pieces dedicated to the Polish pope. On the eve of the canonization (April 26th 2014), during the intercessions during the projection of the many-format multimedia show on the façade of the Bishops' Palace in Krakow (mapping in three-dimensional technology) prepared by the Center of John Paul II, the choir performed: "Abba, Ojcze" ("Abba, Father"); "Jesus Christ, You Are My Life"; "Misericordias Domini" as well as "Barka" ("Ship"). Meanwhile, on the day of the canonization (April 27th 2014), there was a concert (as part of the "Koncerty u św. Marcina"/"Concerts at St. Martin's" cycle) organized by the Polish Bach Association, during which the Psalmodia choir presented Stanisław Moniuszko's "Des-dur Mass".

The concert concluding the series took place in Lipowa near Żywiec (June 15th 2014) in the hometown of the Rector of our university, Rev. Prof. Dr. Hab. Władysław Zuziak. The concert consisted of sacred, folk and pop music. During summer vacation, the choir members travelled to France, where their music was presented at the Thirty-Ninth International Congress of Pueri Cantores in Paris (July 9th-13th 2014). The choir also performed in Krakow, presenting a repertoire including the music of Romuald Twardowski.

The celebrations of the 25th anniversary of the Psalmodia choir received financial support from the Marshal's Office of the Lesser Poland Voivodeship as part of the "Mecenat Małopolski 2014" ("Patronage over Lesser Poland 2014") program, the Pontifical University of John Paul II in Krakow, the St. Hedwig the Queen Foundation for the Pontifical University of John Paul II and the PASSIONART Association.

In addition to its didactic and research activity, the Pontifical University of John Paul II does not forget about the spiritual formation of its students and staff. The Academic Chaplaincy "Patmos" is responsible for it. Each class of lay students has its own chaplain, who celebrates Mass for them, preaches ascetic conferences and speaks with students individually about their spiritual needs. The Masses take place at least once a month, and the formation meetings with conferences typically take place during Advent and Lent. They are an integral part of retreats given in those liturgical times. Rev. Dr. Lucjan Bielas coordinates all chaplaincy activities. Meanwhile, students studying for the priesthood receive spiritual and pastoral formation in their seminaries. Lay students meet for prayer in the Chapel of St. John Paul II, which is located in the university building at 1 Franciszkańska Street. 
Concern for students also includes help in solving their problems. The newly formed Ster ("Helm") Student Clinic. This is a common initiative of the Academic Chaplaincy "Patmos" and the students of the Faculty of Social Sciences. The clinic helps in solving family crises, in the search for one's own specialist or the financing of one's own research project, or in any other matter that may be complicating student life. The clinic is open to the needs of all of Krakow's universities. Since March 10th 2014, it is located in the university building on 3 Bernardyńska Street.

The university authorities also try to provide the best possible conditions for study for students with disabilities. The Office for Persons with Disabilities takes care of them. For such persons, the Sixth Krakow Days of Integration were organized on April 8th-11 th 2014. The main theme of last year's days was the fullest possible integration with Krakow's academic milieu through athletics, trainings, artistic activity and also the increasing in the accessibility of post-secondary schools for students with disabilities. A novelty of the Sixth Krakow Days of Integration was a cycle of workshops and trainings titled: "Zobacz niepełnosprawność" ("See Disability"), which was directed at both students with disabilities and those without them at the Krakow University of Economics as well as all persons interested in this subject matter. In Krakow, there is an agreement concerning the cooperation of the city's universities to help persons with disabilities. It was signed on October 27th 2010. Six Krakow universities signed this agreement: AGH University of Science and Technology, the Krakow University of Technology, the Krakow University of Economics, the Pedagogical University of Krakow, the Pontifical University of John Paul II and the Jagiellonian University.

The university also remembers its graduates. Since 2011, there is an Association of the Graduates of the Pontifical University of John Paul II in Krakow "Academia Nostra". This association is autonomous and its members are the graduates of our university since the beginning of its post-war history and so all who once studied at the Pontifical Faculty of Theology in Krakow, later at the Pontifical Academy of Theology and presently at the Pontifical University of John Paul II in Krakow. Its purpose is to strengthen the bonds between persons associated with our university, bolster our graduates' connection with their university and to promote the academic achievements of their alma mater both in Poland and abroad. The association is in the early phase of its development.

Our university's library is a specialized one. It takes part in the creation of an all-Polish system of exchange of library information and the work of the Krakow Library Group, the Nukat Union Catalog of Polish Research Libraries and the FIDES Federation of the Polish Church Libraries. The library continues to expand its catalog based on the VTLS integrated information system (as of December 2014, the number of recorded titles was 199,052; meanwhile, the number of recorded continuous publishers was 5,040, also as of December 2014). This catalogue is 
available online in the form of a database. The library's collection was used by 12,463 permanent readers in 2014 . In the 2014 , the library was enriched by 5,562 volumes of books, 141 individual inventory multimedia collections and 974 individual inventory journals. In 2014, the library's book collection totaled 387,277 volumes. In 2014, the library acquired 607 operational journals, both domestic and foreign. Most foreign journals receive Analecta Cracoviensia in return.

The St. Hedwig Queen of Poland Foundation for the Pontifical University of John Paul II in Krakow is responsible for the collecting of financial resources aiding the activities of the university. Although since January 1st 1998 (the bill was passed on June 26th 1997) the university receives subsidies from the state budget, they do not cover all expenses above all because these subsidies were intended only for the salaries of didactic staff and for material aid to students. The situation improved after the amendment of the aforementioned bill (on December 2nd 2009) as a result of which: "The Pontifical University of John Paul II in Krakow receives subsidies and other funds from the state budget according to the procedures in force for public universities". However, these subsidies presently cover 72 percent of the university's expenses and do not yet cover the expenses for investments, because the latter are given in a separate proceeding (appropriately prepared grant requests are necessary) depending on the capacities of the state budget. Missing financial resources must thus be covered by a different source. For this reason the foundation popularizes the university's activity with the help of various available funds, encouraging donors to support it.

The foundation applies for financial funds also by participating in contests for projects whose aim is the development of culture announced by state institutions. In this way, the foundation has received financial support to continue its cataloguing and digitalization of its archival resources in the Church and Hospice of St. Stanislaus in Rome (Parts II and III of the task were realized under the title: "The Digitalization of Archival Documents in the Archives of the Church and Hospice of St. Stanislaus in Rome").

In the past year, the foundation selected eight student projects (among 31 proposals) to finance from the foundation's own funds by way of a contest. In making its selection, the foundation used the following criteria: the aim of the project, the project's academic-didactic content, the scale of the project, the project's planned effects, one's own financial contribution and the received one and the promotion of the foundation. The subsidized projects are: Jubileusz 25-lecia chóru Psalmodia ("The 25th Anniversary of the Psalmodia Choir", realized by the Psalmodia choir); Ich Areopag wiary ("Their Areopag of Faith", realized by the students of journalism and social communications as well as seminarians of the Major Seminary of the Archdiocese of Krakow); Biblioteki i archiwa parafialne: Materiały odzyskane dla pracy badawczej ("Parish Libraries and Archives: 
Materials Regained for Research Work", realized by students of the first year of the Second Cycle Master of Arts Studies in History with the Archival Studies specialization as well as students of the second year of History with the Eastern Europe specialization under the guidance of Rev. Prof. Dr. Hab. Jan Szczepaniak); the VII Ogólnopolska Interdyscyplinarna Konferencja z cyklu „Wokół myśli Michała Hellera" (the Seventh All-Polish Interdisciplinary Conference from the "Concerning the Thought of Michał Heller" cycle, realized by the Philosophy Student Circle); Wysocki nieznany ("Unknown Wysocki”, organized by students of the first year of Second Cycle Master of Arts studies in History with a specializing in "Eastern Europe" under the guidance of Dr. Hab. Jakub Sadowski); a semester-long Italian language course at the B1 level (students of journalism and social communications under the guidance of Ms. Kalina Kreczko); the activity of the Dragon Boat Lodz Section of the Pontifical University of John Paul II in Krakow (students belonging to the "Dragon Boat Lodz Section" sports club); the reactivation of the student theater (the Theatrical group at the Journalist Academic Circle); the "Muzealia w konserwacji 2014" academic conference ("Museum Collections in Conservation 2014"; the Scientific Circle of Students of the Institute of Art History and Culture); the all-Polish academic conference titled: „Na wojnie każdy umiera żołnierzem”. Historia jednostek wojskowych walczących na frontach II wojny światowej ("'Everyone Dies a Soldier at War': The History of Military Units Fighting on the Fronts of World War II", students of history under the guidance of Rev. Dr. Mariusz Trąba); Objazd naukowy „Bałkany”: Serbia i Macedonia (“A Scientific Detour of the 'Balcans': Serbia and Macedonia"; the Student Tourism Circle); the publication Misterium stowa. Modlitwa ("Mystery of the Word: Prayer"; graduate students at the Faculty of Theology under the direction of Rev. Dr. Hab. Bogdan Zbroja); student internships in the Kyiv archives (students of History, with a specialization in "Eastern Europe" under the direction of Dr. Marian Wołkowski-Wolski); Dbaj o PAMIĘĆ i zachowaj TOŻSAMOŚĆ. Czytamy ostatnią książkę Jana Pawła II ("Take Care of MEMORY and Retain your IDENTITY: We Are Reading John Paul II's Last Book"; students under the guidance of Dr. Tomasz Kornecki); and the students' gift on the occasion of the canonization of Blessed John Paul II - the issuing of a disc with the recordings of students from the first year of the Second Cycle Master of Arts Studies in Journalism and Social Communications (the Theatrical Section of the Journalistic Academic Circle).

On the occasion of the canonization of John Paul II, the foundation decided to mint a commemorative medal with an image of the sainted pope and the university coat of arms. The medal is available in gold, silver and bronze versions. Profits from its sale will support the statute activity of the foundation, which supports the Pontifical University of John Paul II in Krakow. 
In addition to the medals, the foundation also prepared a coffee table book titled: Gaudium veritatis. Temu, który uczy, jak stużyć prawdzie ("Gaudium Veritatis: To He Who Teaches Who to Serve the Truth", Krakow 2014, pp. 94), which presents John Paul II's ties to our university. It contains the memories of all our Rectors as well as unique photographs from their private collections as well as from the University Archives and the Archives of the Metropolitan Curia. His Eminence Cardinal Stanisław Dziwisz was the honorary patron of the book, and its media sponsors were: Dziennik Polski, Gość Niedzielny, Radio Plus and the franciszkanska3.pl website.

On this occasion, the foundation's management would like to express its gratitude to all the donors for showing us support, kindness and readiness to give aid. A Mass was celebrated for all these donors in the Church of St. Mark the Evangelist in Krakow.

Regular events in the life of the university also include prayers for its deceased staff and for all the deceased staff of all universities and post-secondary schools in Krakow and Lesser Poland. Each year in November, a ceremonious Mass is celebrated in St. Anne's Collegiate Church in Krakow. Then, the academic milieu prays for all those who in the past year passed on to eternity. In the past academic year, this took place on Monday November 18th 2013.

In conclusion, it is worth mentioning also those persons who left us forever in the past academic year. Last year's chronicle of mourning of the university is longer than usual. It begins with Rev. Prof. Dr. Hab. Jan Kracik, who left us for the Lord on April 24th 2014 at the age of 73. The professor and priest was known as an outstanding representative of the academic milieu in Krakow, an acute seeker of truth and a valued academic teacher. He published approximately 450 works, including more than a dozen books. He popularized the results of his research in the Tygodnik Powszechny weekly and the Znak monthly, not infrequently presenting them in a colorful and blunt way.

Our academic community also parted with Rev. Dr. Hab. Marian Jakubiec, who passed on to eternity on July 21 st 2014 at the age of 85 . He was a lecturer of catechetics, the director of the Catechetical Department of the Metropolitan Curia in Krakow and the parish priest of the All Saints Parish in Krakow. In 2003, he received the Bene Merenti papal decoration for his outstanding contributions to the Church of many years. He published academic works about catechesis.

It was also with sadness that we learned about the death of Ms. Anna Osławska. She left for her Father's Hose on August 18th 2014 at the age of 57. For many years, she was a lecturer in rhetoric and the promotion of culture, and also organized theatrical life at our university. She was the author of many texts for theater, radio and television and was the co-creator and Artistic Director of Theatrum Mundi. She specialized in artistic education, the culture of language and the history of theater. 
Rev. Prof. Dr. Hab. Marian Kanior, OSB, left us on August 26th 2014 at the age of 85 . He was an academic-didactic staff member at the Faculty of Church History (presently the Faculty of History and Cultural Heritage). He specialized in the history of theology and the history of religious congregations. He authored more than 100 publications, including nine books.

We also were in mourning when we learned of the passing of Rev. Prof. Dr. Hab. Tadeusz Dionizy Łukaszuk, O.S.P.P.E., on September 5th 2014. He was 80 years old. He was a scientific didactic staff member of the Faculty of Theology, its Associate Dean in 1997-2000 and the Director of the Chair of Dogmatic Theology. He lectured in dogmatic theology, specialized in Christology, eschatology and the theology of icons. He authored more than 70 academic publications, including four books.

We ask Divine Mercy for our deceased university staff and they remain in our grateful memory, trying to imitate their example of human goodness and academic honesty.

Rev. Jan D. Szczurek Translation: Filip Mazurczak 